\title{
Founding a Metaphysics of Light in Proclus' Universe: Berthold of Moosburg's Theory of Forms
}

\author{
Sylvain Roudaut \\ Stockholm University
}

\section{Introduction}

Like many of his philosophical standpoints, the theory of formal causality that Berthold of Moosburg developed in his Exposition on the Elements of Theology results from an original combination of the doctrines inherited from Albert the Great and the so-called German Dominican school. Since it is intimately connected to the notion of flux and the concept of essential cause, Berthold's theory of formal causation is an essential aspect of his intellectual project that sets it apart from the dominating Aristotelian framework of his time. His account of formal causation brings together his positions on universals, his account of cognition and the structure of the soul and, most of all, the production of the physical universe in its physical and cosmological dimensions. It is known that, on these topics, Berthold builds on his Dominican predecessors' developments on the theory of emanation. But his conception of formal causality cannot be entirely superimposed upon these earlier doctrines, for two main reasons.

On the one hand, Berthold intends to harmonize many sources that, as we will see, are sometimes divergent regarding the nature of forms and were partly rejected by his main influences. On the other hand, his exposition on the Elements of Theology forces him to adjust his theory of forms to its precise content. The Elements describe Form as something posterior to Being. ${ }^{1}$ Defining the first cause as superintellectual and superessential (Proposition 115), Proclus does not seem to allow the description of God as the first form or the form of forms, a phrase often used in the Latin tradition to describe God, which Berthold takes up. ${ }^{2}$ But while the Elementatio seems on the face of it incompatible with

1 Proclus, The Elements of Theology, ed. E.R. Dodds (Oxford: Oxford University Press, 1971), Prop. 74, p. 70-71.

2 Berthold of Moosburg, Expositio super Elementationem theologicam Procli. Propositiones 108135, ed. F. Retucci (Hamburg: Meiner, 2011), 112D, p. 27, l. 79-84. 
a pure metaphysics of form, Berthold's hermeneutical tools for interpreting it - rooted in the Latin theological and philosophical tradition - are strongly dependent from the vocabulary of forms and hylomorphism. How, then, did the Exposition on the Elements of Theology lead Berthold to a specific account of formal causation? And to what extent did he have to take some distance from ideas defended on the subject by Albert the Great and his followers?

A first answer to these questions is that Berthold aims at the same time to adapt the Elements to a Christian perspective, to the specific theory of causation built by his Dominican predecessors and, first of all, to the philosophical terminology of the period. Indeed, Berthold cannot fully explain Proclus's text without using - and modifying to a certain extent - the vocabulary of Aristotelian hylomorphism. ${ }^{3}$ This answer, while correct in outline, is still too general to be satisfying, and needs to be refined regarding the precise points where Berthold's status as a commentator of Proclus led him to original views. Several studies have already highlighted the way Berthold grounds his doctrine of causality on a wide range of philosophical material leading him to a highly systematized theory of emanation. ${ }^{4}$ However, Berthold's theory of forms is intended to encompass a general account of the various levels of reality - of which the formal flux is only one side - that has not yet been studied in detail.

This paper aims to fill this gap by analyzing Berthold's most distinctive ideas on this topic. His most original views on forms can be divided into three categories: first, the way Berthold's conception of forms supports his theory of light; second, the way he defines form as a universal principle capable of

3 As is known, even if the use of hylomorphic discourse in Proclus is common and betrays the influence of Aristotle, Proclus refuses hylomorphism as a general ontological theory and a coherent theory of the soul. See H.S. Lang, "The Status of Body in Proclus," in D.D. Butorac, D.A. Layne (eds), Proclus and his Legacy (Berlin / Boston: De Gruyter, 2017), p. 69-82; C. Russi, "Causality and Sensible Objects: A Comparison between Plotinus and Proclus," in R. Chiaradonna, F. Trabattoni (eds), Physics and Philosophy of Nature in Greek Neoplatonism. Proceedings of the European Science Foundation Exploratory Workshop (Il Ciocco, Castelvecchio Pascoli, June 22-24, 2006) (Leiden / Boston: Brill, 2009), p. 145-171; G. Van Riel, "Proclus on Matter and Physical Necessity," in Chiaradonna, Trabattoni (eds), Physics and Philosophy of Nature, p. 231-255.

4 E. Ludueña, La recepción de Eriúgena en Bertoldo de Moosburg: Un aporte sobre la Escuela de Colonia (Saarbrücken: Publicia, 2013); K. Flasch, "Procedere ut imago. Das Hervorgehen des Intellekts aus seinem göttlichen Grund bei Meister Dietrich, Meister Eckhart und Berthold von Moosburg," in K. Ruh (ed.), Abendländische Mystik im Mittelalter (Stuttgart: Metzler, 1986), p. 125-134; M.R. Pagnoni-Sturlese, "Filosofia della natura e filosofia dell'intelletto in Teodorico di Freiberg e Bertoldo di Moosburg," in K. Flasch (ed.), Von Meister Dietrich zu Meister Eckhart (Hamburg: Meiner, 1984), p. 115-127; E. Paschetto, "L'Elementatio theologica di Proclo e il Commento di Bertoldo di Moosburg. Alcuni aspetti della nozione de causa," Filosofia 27(1976), p. 353-378. 
distinct modes of existence; and finally, the way Berthold justifies the gradation of beings described in the Elements using hylomorphic terminology. It will become clear that, far from being disconnected, these themes represent three sides of a unified and original theory of forms through which, besides his first ambition to explain the eternal realities and the beyond-wisdom contained in the Elements, Berthold also takes positions on important debates of his time.

\section{The Identification of Light and Form}

\subsection{Berthold's Sources}

One of the fundamental principles lying at the core of Berthold's conception of form is its identification with light, which underlies the constant comparison between the process of emanation and the diffusion of light. The image of light is arguably central to every Neoplatonic doctrine, but it acquired a particular importance in the school of Cologne and especially in Berthold's system. ${ }^{5}$ More than a simple metaphor of creation, light diffusion came to represent a theoretical model for the mechanism of emanation. Translated into more technical concepts, the thesis of a diffusion of essences from the divine unity to created beings is captured by the expression forma fluens describing this essential dynamism, which Berthold analyzes in Proposition 18. The association between the notions of form and flux echoes one of the most important debates in 14th-century natural philosophy about the definition of motion. ${ }^{6}$ Quite unrelated to this debate in Berthold's work, the expression rather takes us back to Albert the Great.

Albert mainly presented this concept in his De causis et processu universitatis. In this work, Albert called forma fluens the process by which divine perfections flow from higher realities to the sensible world. ${ }^{7}$ This phrase enabled

5 B. Faës de Mottoni, "Il problema della luce nel commento di Bertoldo di Moosburg all'Elementatio theologica di Proclo," in Studi medievali 16(1975), p. 325-352.

6 A. Maier, "Die Wesensbestimmung der Bewegung," in Die Vorläufer Galileis im 14. Jh. (Roma: Edizioni di Storia e Letteratura, 1949), p. 9-25; A. Maier, "Forma fluens oder fluxus formae," in Zwischen Philosophie und Mechanik (Roma: Edizioni di Storia e Letteratura, 1958), p. 61-143; J.M.M.H. Thijssen, "The Debate over the Nature of Motion: John Buridan, Nicole Oresme and Albert of Saxony. With an Edition of John Buridan's Quaestiones super libros Physicorum, secundum ultimam lecturam, Book III, Q. 7," in Early Science and Medicine 14/1(2009), p. 186-210.

7 S. Milazzo, La théorie du fluxus chez Albert le Grand. Principes philosophiques et applications théologiques, PhD diss. (Université de Metz, 2007) <URL:https://hal.univ -lorraine.fr/tel-01749027/document>; A. de Libera, Métaphysique et noétique. Albert le Grand (Paris: Vrin, 2005), p. 143-209; T.M. Bonin, Creation as Emanation. The Origin of Diversity in 
Albert to reconcile the vertical dimension of formal causation with the idea of participation suggested by the image of flux, while insisting on the difference between the notion of flux and the usual four Aristotelian causes. ${ }^{8}$ In his works, Albert already suggested a link between his theory of universals and the nature of light. He explained how universals, in other words, forms or essences, could be related at the same time to distinct individuals and have distinct modes of existence (ante rem, in re, post rem). Albert's conception of universals allowed forms to exist as intelligible models, in concrete beings, or in the intellect while remaining self-identical as essences. ${ }^{9}$ To this extent, the properties of light correspond to Albert's views on essences: the nature of light is such that it remains the same in its source and in the medium in which it is propagated. For this reason, the flux of forms can be conceived in terms of light. This identification of light and form therefore enables Albert to ground the thesis according to which forms remain essentially the same in their source and in their medium of diffusion, so to speak. ${ }^{10}$

On this point, however, Albert's influence on Berthold is only one among others. One of his most important sources is the Liber de intelligentiis of Adam Pulchrae Mulieris, which draws on the notion of light as well as optical

Albert the Great's On the Causes and Procession of the Universe (Notre Dame: Notre Dame University Press, 2001).

8 Albert the Great, De causis et processu universitatis a prima causa, ed. W. Fauser (Münster i.W.: Aschendorff, 1993), lib. I, tr. 4, c. 1, p. 42-43, l. 38-3: Non enim fluit nisi id quod unius formae in fluente et in eo in quo fluit fluxus. Sicut rivus eiusdem formae est cum fonte, a quo fit fluxus, et aqua in utroque est eiusdem speciei et formae. Quod non semper est in causato et causa. Est enim quaedam causa aequivoce causa. Similiter non idem est fluere quod univoce causare. Causa enim et causatum univoca in alio causant aliquando. A fonte autem a quo fit fluxus non fluit nisi forma simplex absque eo quod aliquid transmutet in subiecto per motum alterationis vel aliquem alium. [...] Fluxus est simpliciter emanatio formae a primo fonte, qui omnium formarum est fons et origo.

9 Albert the Great, Physica, ed. P. Hossfeld (Münster i.W.: Aschendorff, 1987), lib. I, tr. 1, c. 6, p. 10; Albert the Great, Super Porphyrium de VUniversalibus, ed. M. Santos Noya (Münster i.W.: Aschendorff, 2004), 2, 3, p. 24; Albert the Great, Metaphysica, ed. B. Geyer (Münster i.W.: Aschendorff, 1960), lib. v, tr. 6, c. 5, p. 285. On Albert the Great's theory of universals, see T. Noone, "Albert and the Triplex universale", in I.M. Resnick (ed.), A Companion to Albert the Great. Theology, Philosophy and the Sciences (Leiden / Boston: Brill, 2013), p. 619-626; de Libera, Métaphysique et noétique, p. 211-264; A. de Libera, La querelle des universaux. De Platon à la fin du Moyen Âge (Paris: Seuil, 1996), p. 177-206; A. Bertolacci, "Le citazioni implicite testuali della Philosophia prima di Avicenna nel Commento alla Metafisica di Alberto Magno: analisi tipologica", in Documenti e Studi sulla Tradizione Filosofica Medievale 12(2001), p. 179-274; G. Wieland, Untersuchungen zum Seinsbegriff im Metaphysikkommentar Alberts des Grossen (Münster i.W.: Aschendorff, 1972), p. 41-46. Albert the Great, Metaphysica, lib. v, tr. 6, c. 5, p. 285, l. 73-77. 
concepts, such as diffusion and reflection, to explain the process of creation. ${ }^{11}$ From the Liber de intelligentiis, Berthold borrows the idea of treating notions such as light refraction, multiplication or radiation not only in their physical meaning but also in a metaphysical sense. The diffusion of light and its reflection, in particular, can serve to model the processive and conversive movements of the emanative flux. ${ }^{12}$ But Berthold's closest source for the identification of light diffusion and formal causality is Ulrich of Strassburg. More than in Albert's works, the comparison of form and light in Ulrich's thought not only represents a figure of speech, but expresses a relation of identity between the two terms, including when the meaning of light is broadened from its physical sense to the analysis of creation. In this respect, the divine activity of producing all existing forms is an intellectual light. ${ }^{13}$ Ulrich's work ties together Albert's theory of universals and the identification of light and form. ${ }^{14}$ Because Ulrich does not integrate these views to a radical henology like Berthold will do - the notions of light and form remain associated with the concept of being. As a consequence, the equivalence of light, form and being is an essential aspect of the De summo bono. ${ }^{15}$

Berthold takes up these convergent influences. Like Ulrich, frequently cited when he tackles the topic, Berthold takes light from a metaphysical point of view as more than a mere metaphor. In the Exposition, light is also defined as

11 Adam Pulchrae Mulieris, De intelligentiis, in C. Baeumker (ed.), Witelo, ein Philosoph und Naturforscher des XIII. Jahrhunderts (Münster i.W.: Aschendorff, 1908), p. 1-71. The influence of this work on Berthold has been analyzed in detail by de Libera; see A. de Libera, La mystique rhénane, d'Albert le Grand à Maître Eckhart (Paris: Seuil, 1994), p. 410-423.

12 A. de Libera, La mystique rhénane, p. 419sq.

13 Ulrich de Strassburg, De summo bono. Liber 1, ed. B. Mojsisch (Hamburg: Meiner, 1989), lib. I, tr. 1, c. 2, p. 9, l. 71-72: [...] lumen divini intellectus, quod est hypostasis omnium formarum.

14 Ulrich of Strassburg, De summo bono. Liber 3, Tractatus 4-5, ed. S. Tuzzo, lib. III, tr. 4, c. 7, §2, p. 32, l. 22-32; De summo bono. Liber 4, Tractatus 3, ed. A. Palazzo, lib. IV, tr. 3, c. 2, $\S 3$, p. 37, 1. 503-505; on the reception of Albert's doctrine in Ulrich, see A. de Libera, "Ulrich de Strasbourg, lecteur d'Albert le Grand," in Freiburger Zeitschrift für Philosophie und Theologie 32(1985), p. 105-136.

15 See for instance Ulrich of Strassburg, De summo bono. Liber 2, Tractatus 1-4, ed. A. de Libera, lib. II, tr. 3, c. 4, §3, p. 55, l. 35-39; lib. II, tr. 3, c. 5, §3, p. 65, l. 52-53; Ulrich of Strassburg, De summo bono. Liber 2, Tractatus 5-6, ed. A. Beccarisi, lib. II, tr. 5, c. 10, §2, p. 6o, l. 30-31; Ulrich of Strassburg, De summo bono. Liber 3, Tractatus 4-5, ed. S. Tuzzo, lib. III, tr. 5, c. 6, §5, p. 8o, l. 131-133; Ulrich of Strassburg, De summo bono. Liber 4, Tractatus 1-2,7, ed. S. Pieperhoff, lib. IV, tr. 2, c. 5, §18, p. 104, l. 328-329; Ulrich of Strassburg, De summo bono. Liber 4, Tractatus 2,8-14, lib. IV, tr. 3, c. 1, §14, p. 11, 1. 219-220. See F.J. Lescoe, God as First Principle in Ulrich of Strasbourg: Critical text of Summa de bono, IV, 1 (Alba House: New York, 1979), p. 113sq; C. Putnam, "Ulrich of Strasbourg and the Aristotelian Causes," in J.K. Ryan (ed.), Studies in Philosophy and the History of Philosophy, vol. 1 (Washington, D.C.: The Catholic University of America Press, 1961), p. 139-159. 
the first form, and this identification results in a systematic analogy between the causal activity of forms and the mode of action proper to light:

De primo notandum, quod 'forma probatur per hoc esse, quod prima causa est pura lux formalis, et quia causat per essentiam suam, sequitur necessario, quod eius effectus sit diffusio formalitatis: hoc enim est causalitas essentialis, sicut lux essentiali causalitate et formali nihil causat nisi lumen, talis autem diffusio est formale esse omnium.' ${ }^{16}$

\subsection{Berthold's Metaphysics of Light}

Insofar as Berthold grants to light an eminent role, he is willing to define it as a special type of form. Light enjoys a particular status, for its features are different from the process of information typical of other forms. Like an essential cause, the diffusion of light entails the presence in another subject of the same form having a different being (secundum aliud esse).${ }^{17}$ According to Berthold, this property is not exemplified only by physical light. In Proposition 36 , he distinguishes three types of light: natural, intellectual and supersubstantial. Whereas intellectual light pertains to the level of intelligence, supersubstantial light refers to the divine activity of emanation. On the basis on this distinction, Berthold can establish a series of analogies between these different types of light through a principle of proportionality, e.g. between physical and intellectual light: "omnino eodem modo proportionaliter se habet in luce intellectuali, sicut dictum est de luce corporali"18 By virtue of its immaterial character, intellectual activity is analogous to the transparency of an illuminated medium. Because of its simplicity, intellectual light is analogous to the com-penetration of physical light on the sensible plane. The multiplication of light reflects on the sensible plane the diffusing process of intellectual perfection that Berthold

16 Berthold of Moosburg, Expositio, 112D, p. 27, 1. 73-77, cited from Ulrich of Strassburg, De summo bono, lib. IV, tr. 2, c. 5, §2, p. 94, l. 18-23.

17 Berthold of Moosburg, Expositio super Elementationem theologicam Procli. Propositiones 35-65, ed. A. Sannino (Hamburg: Meiner, 2001), 36A, p. 15, l. 14-20: [...] lux et color, ratione suae originis, quae est lumen in perspicuo, et hoc sive terminato quoad colorem sive conculcato quoad lucem, ex proprietate naturae suae non sic absolute informant sua subiecta sicut aliae formae physicae, puta calor et huiusmodi, sed informant ea in quodam ordine ad extra sua subiecta, quo scilicet se ipsas diffundant et multiplicent et faciant extra sua subiecta in alia, et hoc secundum aliud esse, quam habeant in suo proprio subiecto. See also $36 \mathrm{D}$, p. 16, l. 44-5o.

18 Berthold of Moosburg, Expositio, 36E, p. 19, l. 165-166; see also 36B, p. 17, l. 105; 37B, p. 24, l. 81-82; p. 25, l. 111. 
defines as a forma radians ${ }^{19}$ in order to express its communicability. ${ }^{20}$ Just like a polished surface does not retain physical light but transmits it without modifying its nature, one being reflects intellectual light toward another one without altering its essence. ${ }^{21}$ Thus, the reflection of physical light provides a theoretical model for explaining the conversive movement of created intellects toward their cause.

But this analogy can also be extended to analyze the activity of the divine (supersubstantial) light. More precisely, Berthold intends to conceptualize in terms of light diffusion the Neoplatonic thesis according to which created beings continuously depend on the causal flux of the first cause. To do so, Berthold needs to translate the purity and immediateness of this vertical causality into the vocabulary of hylomorphism. To this end, he relies on an interesting aspect of Dietrich of Freiberg's own theory of formal causation, namely his theory of forma perfectionalis. In several works, Dietrich had defined particular entities that he called perfectional forms. ${ }^{22}$ Perfectional forms have four properties: their inherence in substances depends on prior dispositions; they are not composed of genus and species; they do not appear through continuous motion, but through direct transmutation; they do not have proper contraries. ${ }^{23}$ This concept is an original construction of Dietrich's that does not fully correspond to the usual meaning of the scholastic term perfectio: the soul of an animate being, for instance, cannot be counted as a perfectional form. According to Dietrich, perfectional forms belong to the class of secondary acts, even though a secondary act is not necessarily such a form (for instance, the act of speaking in comparison with the ability to speak is not such a form). Since they do not meet any resistance from contraries, perfectional forms are not progressively educed from the potency of matter but immediately appear when actualized. Furthermore, these forms are not composed of genus and species. Since being in potency requires the existence of a genus, perfectional

19 Berthold of Moosburg, Expositio, 36A, p. 15, l. 13-14; p. 16, l. 43; 36D, p. 19, l. 156; 37A, p. 22, l. 14, p. 23, l. 49-6o.

$20 \quad$ Berthold of Moosburg, Expositio, 36D, p. 19, l. 167-170.

21 Berthold of Moosburg, Expositio, 37A, p. 23-24, 1. 68-70: Quoniam igitur impossibile est superficiem politam in eo, quod polita, recipere aliquam formam naturalem absolute informantem et quiescentem in ea et denominantem ipsam, sed solum secundum transmissionem et fluxum in aliud [...].

22 Dietrich of Freiberg, De natura contrariorum, ed. R. Imbach (Hamburg: Meiner, 1980), p. 109-114; Dietrich of Freiberg, Utrum in Deo sit aliqua vis cognitiva inferior intellectu, ed. M.R. Pagnoni-Sturlese (Hamburg: Meiner, 1983), p. 313-314; Dietrich of Freiberg, De luce et eius origine, ed. R. Rehn (Hamburg: Meiner, 1985), p. 20.

23 Dietrich of Freiberg, De natura contrariorum, ed. R. Imbach (Hamburg: Meiner, 1980), c. 39-45, p. 109-114. 
forms do not exist in potency within a subject, which explains that the external agent communicates its own essence to it. From these properties, Dietrich deduced that perfectional forms imply a relation of constant and immediate ontological dependence to another agent. He considered them as particular kinds of forms different from substantial and accidental forms. Dietrich first used this notion in the Quaestio utrum in Deo to explain the status of human intellectual understanding and took as examples the acts of sensation and those of the possible intellect. But the most frequent example and the main application of this notion is light, which Dietrich describes as a perfectional form not only in the De luce et eius origine, but also in his treatise on the nature of contraries.

Berthold borrows this concept from Dietrich to explain several theorems of the Elements. Commenting on Proposition 79, he quotes large passages of Dietrich's Tractatus de natura contrariorum to explain how in certain cases a perfection can be instantaneously actualized and not continuously educed from potency to act. ${ }^{24}$ But most of all, Berthold merges Ulrich's identification of light and form together with Dietrich's theory of perfections when commenting on Proposition 143, which contains an explicit reference to light. Berthold takes advantage of Dietrich's concept of perfectional form which allows him to explain the modalities of divine illumination described in the proposition: "Omne quidem, quod alienum a divino lumine fit, illustratur autem omne subito a diis". Berthold needs to justify the immediate character of illumination cast upon creatures expressed by the adverb subito in the proposition. For doing so, Berthold relies on a comparison between light in its physical, intellectual, and supersubstantial aspects, which is justified by the fact that every type of light comes from the divine form as its ultimate cause. ${ }^{25}$

However, Berthold mentions several arguments designed to show that cognitive processes cannot be instantaneous. Quoting Alhazen's De aspectibus, Berthold notes that complex understanding such as the intellection of a syllogism made of several propositions seem to require some time, just like vision in the sensible order. ${ }^{26}$ Nonetheless, Berthold shows that understanding must

24 Berthold of Moosburg, Expositio super Elementationem theologicam Procli. Propositiones 66-107, ed. I. Zavattero (Hamburg: Meiner, 2003), 79 E-F, p. 95, l. 147-157; p. 96, l. 191-202; p. 97, l. 212-217. See also 72C, p. 39, l. 41.

25 Berthold of Moosburg, Expositio super Elementationem theologicam Procli. Propositiones 136-159, ed. F. Retucci (Hamburg: Meiner, 2007), 143L, p. 69, l. 321-324: Unde etiam quaelibet forma, quanto minus habet huius luminis per obumbrationem materiae, tanto deformior est et alienior a divino luminae, et quanto plus habet huius luminis per elevationem supra naturam, tanto pulchrior est.

26 Berthold of Moosburg, Expositio, 143O, p. 72-73, l. 435-450. 
be instantaneous, since intellectual light - just like physical light - implies an immediate relation to an actualizing cause. To do so, he quotes paragraph 44 of the Tractatus de natura contrariorum where Dietrich concluded that perfections only exist by an immediate actualization from an external agent. ${ }^{27}$ Berthold then applies this description to the divine light by an a fortiori argument. Given that physical illumination is an instantaneous actualization, and not a continuous process, it will necessarily be true of divine light, which is more perfect than physical light. ${ }^{28}$ Thus, in order to justify the immediate relation of created beings to the divine, Berthold ties together his metaphysical interpretation of light and Dietrich's theory of perfectional forms. Moreover, unlike Dietrich, Berthold extends the concept of perfectional forms to any operation in the natural and supernatural world, ${ }^{29}$ allowing him to emphasize the hierarchical dependence of the created universe from the higher levels of reality within the framework of an emanative cosmology.

This point is indicative of Berthold's general attitude toward his sources for constructing his theory of forms, and more particularly toward Dietrich. Here, we can see him extending a notion that was not designed to serve this purpose in Dietrich's thought. Dietrich considered as an important principle the Aristotelian axiom that everything tends towards its own perfection. According to him, this end is immediately achieved only in intellects per essentiam semper in actu, whereas other beings need additional operations to realize their nature. But even in his later writings (the De luce and the De natura contrariorum), Dietrich used the concept of "perfectional forms" to explain the physical properties of light and never directly exploited this notion to conceptualize the cosmological order, i.e. to describe the separate intelligences and their operations. Berthold's metaphysical expansion of this concept is notable

27 Dietrich of Freiberg, Tractatus de natura contrariorum, c. 43-44, p. 113: Quamvis autem hoc genus formarum, quas perfectiones voco, sint naturae extraneae a subiecto sicut et hae formae, quae sunt entium principia, quia tamen in natura perfectionum non distinguitur inter actum et potentiam, per consequens non reperietur in eis distinctio inter formam generis et speciei. [...] Unde per consequens huiusmodi formae, quod saepe dixi perfectiones, non habent fieri per motum, sed per simplicem transmutationem eo, quod motus non est nisi de forma in formam, quae sunt eiusdem generis secundum Philosophum in X Metaphysicae.

28 Berthold of Moosburg, Expositio, 143O-P, p. 73, l. 455-470: Sed magister Theodoricus tractatu De natura oppositorum 44 cap. oppositum sentit, ostendendo formas perfectionales 'fieri non per motum, sed simplicem transmutationem' et per consequens 'unaquaeque earum secundum se et absolute respicit suum perfectibile, et ideo adest et abest modo simplici et indivisibiliter suo perfectibili secundum simplicem et instantaneam dependentiam a sua causa. Et sic visio et illuminatio medii secundum eum fit in instanti. See also $78 \mathrm{E}$, p. 89, l. 125 .

29 Berthold of Moosburg, Expositio, 44B, p. 74, l. 61-64. 
from the way he describes the actualization of such forms. Dietrich described it as a "simple transmutation" to emphasize its immediate character by contrast with continuous motion..$^{30}$ Berthold takes a further step and refers to the actualization of these indivisible perfections as a "simple emanation" ("non per motum et transmutationem, sed per simplicem emanationem"). ${ }^{31}$ From this perspective, it appears clearly that Berthold aims to provide a rigorous account of emanation by enriching the terminology of hylomorphism. The concept of perfectional forms allows him to give the notion of intellectual light a literal meaning, and to provide a rigorous justification for referring to God as the first light. ${ }^{32}$

\section{3}

\section{Forms and Universality}

\subsection{Berthold's Sources}

The temporal modalities of illumination are not the only properties that Berthold needs to prove in order to ground his metaphysics of light. Following his main sources on this theme - i.e. Albert, Ulrich, and Adam Pulchrae Mulieris - he also needs to explain how the essence of perfections remains the same despite the division and multiplication following their diffusion from the first cause. The emanative process of creation, understood as the descending movement of a formal flux, requires the elaboration of a theory of essence as a principle capable of different modes of being. In other words, Berthold's doctrine of emanation requires a theory of universal essence. Interestingly, whereas his realism of universals is in line with his Dominican predecessors, Berthold has his own distinctive strategy for presenting the universal forms. His theory of universals gives a new direction to Albert the Great's views on the reality of forms ante rem that are separate from concrete individuals. Berthold's distinction between two types of universals - praedicationis (logical) and separationis (theological) - not only serves to attribute the theory of transcendent universals to the "true" Platonici and to defend them against Aristotle; it also lays the foundation for a dynamic conception of forms. Berthold's realism about universals is much more than a mere semantical standpoint: building on Dietrich's identification of form and essence, ${ }^{33}$ Berthold's theory of universal

$30 \quad$ Dietrich of Freiberg, De natura contrariorum, c. 44, p. 113, l. 11-14.

31 Correction of the CPTMA edition, which gives enumerationem (143P, p. 73, l. 468) instead of emanationem (cf. MS Oxford, Balliol College Library, 224B, f. 212va; MS Vat. lat. 2192, f. 222rb).

32 Berthold of Moosburg, Expositio, 143K-L, p. 68-7o, l. 290-358.

33 Dietrich of Freiberg, Tractatus de quiditatibus entium, eds R. Imbach, J.-D. Cavigioli (Hamburg: Meiner, 1983). It must be noted that despite his proximity with Dietrich on the 
essence allows him to conceive "forms" as dynamic principles contributing to the ontological production of the universe from the higher spheres of reality to the sensible plane.

In fact, the singularity of Berthold's theory of forma universalis lies in the different authorities summoned to justify his realist position on the subject. The most distinctive feature of his theory of universal forms is his frequent and at times surprising use of Ibn Gabirol's Fons Vitae, which Albert the Great had strongly criticized. ${ }^{34}$ Considering only his exposition on Proposition 177 , Berthold quotes this work no less than twenty-six times. ${ }^{35}$ Several of these quotations are significant passages meant to justify Berthold's own ideas. However, this use is surprising because among the Neoplatonic materials available to him, something could hardly be more distant from the system Berthold intends to build than Ibn Gabirol's ontology. It cannot be excluded that Berthold's reliance on authors - like Thomas of York ${ }^{36}$ - more open to Ibn Gabirol's ideas than his Dominican sources explains to a certain extent the numerous citations from the Jewish philosopher. In any case, the ideas exposed in the Fons Vitae do not fit at first sight with his doctrine. ${ }^{37}$ Following the Dominican tradition - and not only the Albertist school - Berthold rejects

analysis of substantial forms, Berthold describes the hylomorphic compound as being made up from two essences - something that Dietrich would strictly deny (Expositio super Elementationem theologicam Procli. Propositiones 184-211, ed. L. Sturlese [Hamburg: Meiner, 2014], 193E, p. 104, l. 139-141: [...] ut composita ex materia et forma: est enim ibi unum esse, sed duae essentiae sibi mutuo unitae essentialiter). The coexistence of the two essential parts in the hylomorphic compound represents the converse relation of an essential cause, since it implies identity in esse but difference secundum essentiam (193E, p. 104, l. 139); see also 1B, p. 75, l. 138-139.

34 B. McGinn, "Ibn Gabirol, The Sage among the Schoolmen," in L.E. Goodman (ed.), Neoplatonism and Jewish Thought (Albany: State University of New York Press, 1992), p. 77-110, esp. p. 96-98. On the influence of the Fons Vitae on Albert's theory of the formal flux, see Bonin, Creation as Emanation, p. 15, p. 96-98, n. 1-3.

35 Berthold's quotations from Avicebron are numerous, especially on the on the theme of form and matter: in Proposition 3 (11 citations); Prop. 4 (14); Prop. 24 (14); Prop. 34 (9); Prop. 36 (3); Prop. 8 o (3); Prop. 83 (4); Prop. 98 (5); Prop. 135 (6); Prop. 145 (5); Prop. 159 (6); Prop. 170 (20); Prop. 172 (7); Prop. 173 (4); Prop. 177 (26); Prop. 187 (9). On Avicebron's influence on Berthold, see A. Beccarisi's contribution in this volume.

36 On Thomas of York's influence on Berthold and the transmission of Neoplatonic materials through his Sapientiale, see F. Retucci's contribution in this volume; see also E. King, "Eriugenism in Berthold of Moosburg's Expositio super Elementationem theologicam Procli," in D. Calma (ed.), Reading Proclus and the Book of Causes. Volume 1. Westerly Scholarly Debates and Networks (Leiden / Boston: Brill, 2019), p. 394-437.

37 For an introduction to Avicebron's metaphysics, see S. Pessin, Ibn Gabirol's Theology of Desire: Matter and Method in Jewish Medieval Neoplatonism (Cambridge: Cambridge University Press, 2013); J. Schlanger, La philosophie de Salomon Ibn Gabirol (Leiden: Brill, 1968). 
the binarium famossissimum, i.e. the two famous ideas constituting the doctrinal core of the Fons Vitae.

On the one hand, Berthold does not subscribe to the plurality of substantial forms in concrete substances. ${ }^{38} \mathrm{He}$ clearly aligns himself with Dietrich's way of defending the position that only one substantial form can be present in a compound substance. The faculties of a being do not indicate different substantial forms, but only different parts of the soul that are virtually included in the unique form inhering in matter. As such, a soul is a single form that is ontologically simple, even though it can be analyzed in several formales intentiones or principia formalia. ${ }^{39}$ The phrases "formal intentions" and "formal principles" are taken up from Dietrich and, as we will see below, play a central role in Berthold's theory of forms. ${ }^{40}$ Just like Dietrich, Berthold employs them to refer to intelligible features representing the parts of a thing's definition, the partes ante totum constituting the nature of a form. ${ }^{41}$ Thus, there is only one substantial form present in a given compound, even if this form can be decomposed, so to speak, into different formal intentions.

On the other hand, Berthold rejects universal hylomorphism, the view according to which every substance without exception is composed from matter and form. Nonetheless, his relation to Ibn Gabirol's doctrine is more

38 Berthold of Moosburg, Expositio, ${ }_{187}$ E, p. 51, l. 310-313: Dico autem istas tres partes unam rationalis animae substantiam essentiare et non esse diversas in corpore, cum nulla forma substantialis uniatur corpori subiecto mediante alia forma substantiali, sed forma perfectior dat corpori subiecto, quidquid dabat inferior, et adhuc amplius. Unde anima rationalis dat corpori humano, quidquid dat anima vegetabilis plantis, quidquid sensibilis brutis, et aliquid ulterius, et propter hoc ipsa una anima secundum substantiam est in homine vegetabilis, sensibilis et rationabilis. Cuius signum est, quod, cum operatio unius partis intenditur, alterius partis operatio impeditur, et quia redundantia fit unius in aliam. See also $47 \mathrm{~B}$, p. 9o, l. 6o-63; 205B, p. 211, 1. 87-93.

39 Berthold of Moosburg, Expositio super Elementationem theologicam Procli. Propositiones 16o-183, eds U.R. Jeck, I.J. Tautz (Hamburg: Meiner, 2003), 171A, p. 110, 1. 45-61.

40 Dietrich's use of the simple term intentiones is by far the most common in his works, but he also employs the phrase formales intentiones in several occasions, see for instance Tractatus de origine rerum praedicamentalium, 4.21, p. 174, 1. 210; 4.33, p. 178, 1. 332; De intellectu et intelligibili, ed. B. Mojsisch (Hamburg: Meiner, 1977), lib. II, c. 16, §1, p. 157, l. 34; Tractatus de accidentibus, 8.4, p. 64, l. 113. For some occurrences of the phrase principia formalia, see Tractatus de origine rerum praedicamentalium, 4.33, p. 178, l. 341-342; 5.44, p. 194, 1. 445; Quaestio utrum substantia spiritualis sit composita ex materia et forma, II.25, p. 335, 1. 267; Tractatus de accidentibus, 3.3, p. 56, l. 62. On Dietrich's concept of intentions, see A. de Libera, "La problématique des intentiones primae et secundae chez Dietrich de Freiberg," in Flasch (ed.), Von Meister Dietrich zu Meister Eckhart, p. 68-94.

41 For the characterization of partes ante totum as principia formalia, see 16A, p. 25, l. 34-35; 19B, p. 6o, l. 87; 32E, p. 211, l. 177-178; 74B, p. 51, l. 49-50; 170H, p. 102, l. 255; 171F, p. 117, l. $261-262$. 
ambiguous on this point. Berthold acknowledges the authorities of Boethius and pseudo-Dionysius stating that spiritual substances are immaterial..$^{42} \mathrm{But}$, in accordance with Proposition 196, he admits the existence of a spiritual body or vehicle perpetually associated with the soul. Although this incorruptible vehicle is different from the material body, Berthold seems to be committed to the view that separate forms are always linked to a potential principle, not unlike the universal matter posited by Ibn Gabirol. Commenting on Proposition 187, Berthold rejects the idea that forms contain matter as part of their essence. Aiming to justify that no soul can be destroyed, Berthold unsurprisingly denies that the human souls and intellects contain matter as an essential part. He gets to this conclusion by an argument from lesser to greater, showing that since vegetative and sensitive souls themselves do not possess an essential relation to matter, it will be impossible to attribute such a relation to higher forms. ${ }^{43}$ Even the form of a stone as a form is immaterial. Indeed, the hylomorphic composition of the form itself would lead to an infinite regress, insofar as the formal part of this composition will also have its own matter, like any element of the compound will have its co-principle, and so on.

\subsection{Universal Hylomorphism and the Problem of the First Principles}

Nonetheless, Berthold finds a useful resource in Ibn Gabirol's idea of a universal form whose progressive multiplication generates the created world. Therefore, he sets up an original strategy to legitimize the meaning of universal matter, existing at every level of creation according to Ibn Gabirol. ${ }^{44}$ Having extensively quoted the Fons Vitae in Proposition 159, Berthold eventually rejects universal hylomorphism as a literal interpretation of Proclus's statement that

42 Berthold of Moosburg, Expositio, 159C, p. 193-194, l. 139-149; 187C, p. 48-49, l. 214-219. According to Berthold, these theological authorities are in line with Aristotle's opinion on the subject.

43 Berthold of Moosburg, Expositio, 187A, p. 43, 1. 39-53: Si igitur aliquam inveniamus formam minus nobilem anima rationali vel totali, quae non habet materiam, omnis anima, de qua agitur, erit omnino immaterialis. Medium istius rationis apparet, quia lapideitas, quae est forma lapidis, inquantum forma non habet materiam, alias enim procederetur in infinitum. Ergo nec forma vegetabilis nec sensibilis nec rationalis nec intellectualis nec divina habebunt in sui essentia materiam. Et ipse Averroes videtur hoc probare specialiter de forma seu anima vegetabili, quia nulla forma, quae non est aliquid praeter hoc, quod est forma, habet materiam aliam quam subiectum, cuius est forma, alias enim secundum totale esse suum non esset in ratione formae. Quod vero anima vegetabilis in plantis et sensibilis in animalibus sint tales formae, manifestum est, quia, si essent aliquid praeter hoc, quod sunt formae et actus corporum, iam non essent virtutes in corpore, nec penderet earum esse ex corpore, cum essent aliquid in se praeter corpora. Si igitur formae ignobiliores sunt simplices et immateriales, multo fortius animae nobiles erunt formae omnino immateriales.

Berthold of Moosburg, Expositio, 159B, p. 191, l. 75-77. 
Limit and Infinity are the first principles of every composite being. ${ }^{45}$ Matter cannot be regarded as an universal principle, because it represents a part of physical substances and as such does not exist in angels and supernatural beings. However, Berthold offers more acceptable interpretations of this idea:

Proprie enim materia dicitur, ubi est admixta privationi, propter quam ipsa est principium transmutationis.

Minus autem proprie seu communiter dicitur de materia, ubi non est admixta privationi, sicut est in caelo, et tamen est ibi sub situ et dimensione, unde et nominatur subiectum potius quam materia ab Averroe super VIII Metaphysicae.

Communius dicitur materia, ubi nec subicitur privationi nec situi, sed tantum dicit potentiale, quod subicitur actui, et sic est in anima partiali et creatura spirituali, scilicet in angelis. Et hoc vult dicere Rabbi Moses in libro, quem vocat Matrem philosophiae cap. 75: 'Omne, inquit, quod est in potentia ad aliquid, attinet materiae, quia possibilitas semper invenitur in materia', actus vero attribuitur formae.

Communissime dicitur materia, ubi etiam excluso tali potentiali solum dicit potentiam determinativam actualis, ubi determinans, scilicet minus actuale, et determinatum, scilicet magis actuale, coincidunt in eandem essentiam et naturam re, licet differant intentione, et talis materia est in animabus nobilibus, intellectualibus hypostasibus et omnibus entibus citra deos. ${ }^{46}$

Thus, in a broader sense, matter can also refer to the principle devoid of privation existing in heavenly bodies, and even to the sort of potentiality that can be found in the partial souls or spiritual creatures like angels. But in the largest sense (communissime) matter refers to an actual potency of determination in which the more actual is not essentially distinct from the less actual, but only intentionally, and in this sense the most noble souls and the intelligences possess some matter. ${ }^{47}$

Having detailed the different meanings of the term "matter", Berthold still has to make sense of the idea of a universal form. But the idea of a form present in every being does not seem fully compatible with Proclus's system. In Propositions 73 and 74 of the Elements, Proclus establishes a hierarchy between

45 Proclus, The Elements of Theology, p. 138-139.

46 Berthold of Moosburg, Expositio, 159C, p. 194, l. 152-166.

47 On the distinction between three types of matter (with a reference to Thomas of York), see also ${ }_{187} \mathrm{C}, \mathrm{p} .47-48$. 
wholes, forms, and being. In Proposition 73, Proclus demonstrates that Being is superior to Wholeness, since every whole participates Being, while the converse is false. ${ }^{48}$ Similarly, according to Proposition 74 of the Elements, eidos, which is rendered in the Latin version by species, is posterior to Being, since every form is a being, while the converse is false (for instance, privation is still a sort of being, but not a form). Wholes are prior to Forms, because the latter are already cut ( Thus, Forms are posterior to Wholes, which are less universal than Being but more universal than Forms. ${ }^{50}$ In this perspective, forms, strictly speaking, only belong to the intellectual level, and not to the divine realm, so that the phrase forma universalis should be restricted to the Intellect. The Intellect, full of forms, can be properly said to be a universal form in the sense that it contains all intelligible models of species, as stated by Proposition 177 and as Ibn Gabirol showed in his Fons Vitae. ${ }^{51}$

At this point, Berthold seems to be caught between the conflicting sources he is willing to harmonize. On the one hand, the definition of God as the highest or first form represents a classic theme of the Latin theological tradition, to which Albert and his followers were not opposed. Berthold himself often describes the first cause as formalius, and sometimes refers to it as the prima forma..$^{52}$ But on the other hand, owing to a distinction taken up from the $D e$ causis, ${ }^{53}$ Berthold sharply differentiates the causal activity of the One, operating per modum creationis, and the secondary causes that operate per modum formae. This latter mode of operation can be called information, determination, or composition. ${ }^{54}$ Furthermore, according to Ibn Gabirol, the forma formarum refers to a created principle. In the Fons Vitae, the concept of

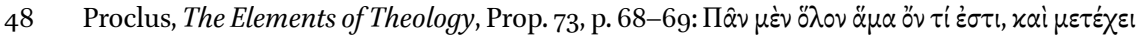

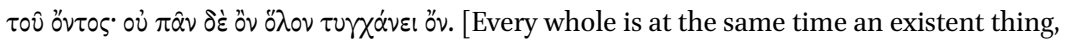
and participates Being but not every existent is a whole - trans. Dodds].

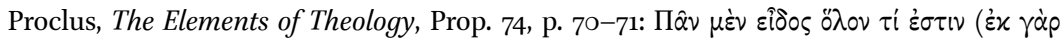

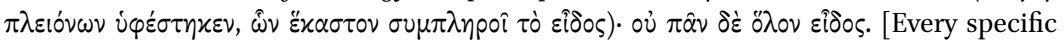
Form is a whole, as being composed of a number of individuals each of which goes to make up the Form; but not every whole is a specific Form - trans. Dodds].

$5^{\circ}$ On Proclus's theory of wholes and universals, see L. Siorvanes, Proclus. Neo-Platonic Philosophy and Science (Edinburgh: Edinburgh University Press, 1996), p. 67-71.

$5^{1}$ Berthold of Moosburg, Expositio, 177A, p. 173, l. 16-2o. See also 173A, p. 127-129.

$5^{2}$ Berthold of Moosburg, Expositio, 112D, p. 27, l. 82, 1. 85.

53 Liber de causis, Prop. XVII(XVIII), p. 86. On the per creationem/per modum formae distinction in Berthold, see Ludueña, La recepción de Eriúgena en Bertoldo de Moosburg, p. 30-31, p. 178, p. 403; E. Ludueña, “Creatio y determinatio en la Escuela Renana: de Alberto Magno a Bertoldo de Moosburg”, in Princípios: Revista de Filosofia 22/37(2015), p. 77-97.

54 In this context, the phrases "information" and "determination" are taken up from Albert the Great and Dietrich of Freiberg (3A, p. 93, l. 37, n. 6), whereas the term "composition" 
universal form refers to the highest created principle of the universe that generates every subsequent being by its conjunction with universal matter. In this system, form and matter represent universal principles in a double sense: first, because they are present in every being; ${ }^{55}$ second, and most of all, because they are the first created principles, whose union generates a series of derived creatures. The First Intelligence, ${ }^{56}$ distinct souls (rational, sensitive, vegetative), ${ }^{57}$ Nature, and finally the physical substance bearing the nine accidents ${ }^{58}$ represent the stages of this descending process. The ultimate cause of everything is independent from the realm of universal form and matter to which God relates only through his will.

Berthold manages to solve this difficulty by reinterpreting in his own way the two first principles that Ibn Gabirol called "universal matter" and "universal form". Berthold replaces those universal principles with the first One (prime unum) and the first infinity (prime infinitas), that is to say the first of the six unitates immediately following the first cause. ${ }^{59}$ Everything comes from these two principles, like Proclus demonstrated using the terms Limit and Infinity just like, in his own way, Ibn Gabirol with the terms form and matter. ${ }^{60}$ But Berthold's solution retains something of Ibn Gabirol's doctrine of a co-production of the whole universe from two principles. Indeed, the prime infinitas that replaces universal matter accounts for the presence of the incohatio formarum in matter and, in this respect, represents the proper cause of multiplicity in the created universe including in the material world.

We can see how, despite many prima facie incompatibilities, Berthold manages to make sense of philosophical material that was not held in high esteem by his Dominican predecessors. Berthold does not follow Ibn Gabirol's scheme of universal emanation, in the sense that the series of emanated beings in the Fons Vitae is quite different from the more complex Proclean universe. Nonetheless, Berthold agrees with Ibn Gabirol on the equivalence of form and universality in a precise sense: what is more universal contains more forms, and the first universal cause virtually contains all perfections as well as specific models informing the created universe, as Proclus had emphasized. However, Berthold cannot have it both ways. His attempt to reconcile Ibn Gabirol with

(denoting the relation between form and matter) stems from Gundissalinus's De processione mundi (4A, p. 104, l. 100).

Avicebron, Fons vitae, ed. C. Baeumker (Münster i.W.: Aschendorff, 1995), lib. I, c. 5, p. 7-8.

56 Avicebron, Fons vitae, lib. v, c. 10, p. 274; lib. v, c. 11, p. 277.

57 Avicebron, Fons vitae, lib. III, c. 46-49, p. 183-188.

$5^{8}$ Avicebron, Fons vitae, lib. III, c. 1, p. 73-74.

59 On this point, see Ludueña, La recepción de Eriúgena en Bertoldo de Moosburg, p. 165-219.

6o Berthold of Moosburg, Expositio, 159G, p. 197, l. 265-269. 
Proclus's henology not only modifies the meaning of the adjective "universal" central to Ibn Gabirol's cosmology, his interpretation also leads him to deviate from Proclus's original text, which did not identify the One with the principle of Limit and located it, so to speak, beyond Limit and Infinity. ${ }^{61}$

\subsection{Conceptual Distinctions}

The reality of universal essences has a direct implication on the internal structure of the universe as Berthold conceives it. Berthold defines an intrinsic relation between the universal character of essences and the ontological properties Proclus attributed to self-constituted realities (antipostata). This relation is characterized owing to Dietrich of Freiberg's guiding reflections on the nature of spiritual substances. ${ }^{62}$ Drawing on Dietrich's analysis, Berthold considers that pure forms - i.e. purely spiritual entities - are species before being individuals, since they are not individuated by quantity nor possess partes post totum. In other words, some beings (like hypostatic intellects) that Berthold calls entia secundum speciem are such that they are, in a sense, "more species than individuals", insofar as they are alien to the individualizing conditions of material existence. Since these beings are higher principles than material entities, their spiritual influence is not limited by matter as in the case of concrete individuals. The fact that they are constituted by pure intelligible perfections, themselves undivided but participated by lower individuals, explains why Berthold refers to these entities as "species before individuals". This priority must not be understood in a chronological sense, but as a type of ontological priority. Concrete individuals, in contrast, are individuals before being a species, since the full actualization of their essential properties implies the development of material dispositions. ${ }^{63}$ Matter and the dimensional quantity attached to it give essences a concrete mode of being, which necessarily entails a certain partibility characterizing the realm of individuals. The partes post totum of a substance (i.e. the integral parts that come along with concrete existence) explain that the operations of corporeal souls do not immediately coincide with their essence and are subject to the division entailed by quantified matter. However, even in the case of partial souls, whose powers are

\footnotetext{
61 Proclus, The Elements of Theology, p. 138-141.

62 Dietrich of Freiberg, Quaestio utrum substantia spiritualis sit composita ex materia et forma, II, p. 335, 1. 252-255: Substantiae enim ingenerabiles et incorruptibiles quantum ad $i d$, quod sunt, prius natura sunt entia ut simpliciter et secundum speciem quam entia individualia; secundario autem et secundo ordine sunt entia individualia.

63 Berthold of Moosburg, Expositio, 187D, p. 5o, l. 26o-263, l. 272-274; for similar analyses, see $20 \mathrm{~A}$, p. 67, l. 81-84; 121D, p. 106, l. 52-6o. On this point, see K. Flasch, "Einleitung", in Dietrich of Freiberg, Schriften zur Naturphilosophie und Metaphysik, p. XXXIII-XXXIV.
} 
divided into distinct parts, the different faculties are different aspects of one single form.

One will note, at this point, that Berthold employs a single concept of form to describe quite different realities. As a matter of fact, regarding the different status of forms and their equivocal meanings, Berthold makes two important distinctions that must be noted. The first is to be found in Proposition 28. Here, Berthold makes a distinction between "substantial form", which refers to a part of the compound substance, and what should more properly be called "essential form". Whereas the former syntagm should be restricted to designate the part of the hylomorphic compound, the latter refers to a form that does not inhere in a subject, but whose perfection is nevertheless participated by it. The essential form designates an intention that more truly informs a subject without becoming one with it:

Voco autem formam substantialem communi nomine pro forma, quae est altera pars compositi, et pro forma essentiali, quae est intentio realis, quae etiam realius et essentialius omni forma substantiali qualitative informat, cum ipsa non faciat compositionem realem cum subiecto suo, forma autem substantialis et subiectum suum ponant in numerum, quamvis unum per essentiam suam penetret aliud. ${ }^{64}$

This distinction echoes the difference Berthold establishes in Proposition 25 between the term essentia, which should be restricted to the entia secundum speciem, and the term substantia that refers to the level of concrete beings beginning with celestial bodies. ${ }^{65}$

A second important distinction can be found in Berthold's exposition on Proposition 194. There, Berthold underlines the difference between the closely related terms species and forma or idea, which are very often confused according to him. Berthold does not quote the famous remarks made by Augustine on this problem, ${ }^{66}$ but he recalls that the term species refers to the specific reasons

64 Berthold of Moosburg, Expositio, 28E, p. 177, l. 210-215.

65 Berthold of Moosburg, Expositio, 25C, p. 142, l. 166-172: Dico autem substantiam, secundum quod condividitur contra essentiam, quae est ens ut simpliciter, ut iam dictum est, et secundum speciem. Substantia vero est ens hoc cum proprietate individuali. Et sic ratio sub: stantiae proprie loquendo in separatis incipit in anima totali, quae unita corpori caelesti constituit cum eo unum, cuius potentia sive ratio agendi est substantia caeli, prout est composita ex anima totali et corpori caelesti. See also 178D-E, p. 196, l. 236-253, where Berthold tries to establish the compatibility of Plato's theory of Ideas with Aristotle's identification of formal, final, and efficient causes.

66 Augustine, De diversis quaestionibus octoginta tribus, ed. A. Mutzenbecher (Turnhout: Brepols, 1975), p. 70-71. 
making up the essence of things. These specific reasons express intelligible features possessing a universal mode of being devoid of individual character. By contrast, forma or idea refer rather to the model from which an individual entity comes to being. Once again, Berthold follows a distinction that Dietrich previously articulated in the De visione beatifica. In this work, Dietrich underlined the difference between the rationes rerum present in the divine mind and the ideas. Whereas the former only constitute the pure intelligible features of a given species that do not determine its individual aspects (therefore constituting res secundum speciem), the latter phrase refers to the exemplar form from which individual things derive. ${ }^{67}$ In Proposition 194, Berthold employs his collage technique to make his point: making Dietrich's distinction more precise, Berthold adds that ideas exist in mobile causes, whereas species belong to the level of hypostatic intellects. The distinction between universal and individual form is therefore emphasized and complements the theory of "beings according to species":

Tales autem species differunt ab ideis sive formis; respiciunt enim solum res, immo respiciendo constituunt secundum esse specificum simpliciter vel prout determinatur ad individuum modo, quo iam dictum est; solius autem esse specifici est ratio sive definitio. Ideae autem sunt formae exemplares, secundum quas ad quarum imitationem procedunt res secundum esse individuale.

Est et alia differentia specierum et idearum. Species enim, prout sunt idem, quod rationes essentiales causales, inexistunt causes simpliciter immobili et intransmutabili, qualis est intellectualis hypostasis - sic namque species derivatae, utpote intransmutabilis substantiae, procedunt ab immobili causa, per 76 -; ideae autem inexistunt causae vel per se mobili vel ex se mobili ratione eius, quod est per se mobile.

Et haec sufficiant de specierum et idearum differentia, si accipiantur secundum proprias rationes, licet frequenter unum pro alio accipiatur. ${ }^{68}$

From this perspective, we can see that the reality of universal essences according to Berthold participates to the very structure of the universe. The causal dynamism of beings secundum speciem marks the border between these selfsubsistent realities and the sensible world derived from them.

67 Dietrich of Freiberg, De visione beatifica, ed. B. Mojsisch (Hamburg: Meiner, 1977) 1.2.1.1.3, p. 38-39, l. 65-72.

68 Berthold of Moosburg, Expositio, 194D, p. 110-111, l. 100-113. 


\subsection{Forms, Intentions, and Formal Principles: An Extended Hylomorphic Vocabulary}

By themselves, however, those distinctions appear insufficient to fully characterize the complexity of Proclus's universe and its numerous ontological layers. Above the level of the hypostatic Intellect, the six divine beings (prime infinitas, prime entitas, prime vitas, prime intellectualitas, prime animealitas, prime naturalitas) represent the most formal level of the universe immediately following the first One. These entities cannot be adequately described by the Aristotelian idea of form understood as an essence composed of genus and specific difference. Rather, Berthold describes these entities with the concepts of "formal intention" or "formal principle". The first One is one single intention (intentio unius). Since a "formal intention" represents a perfection that can be participated by the effects flowing from the first cause, Berthold alternatively uses the expression "formal principle" to designate it: "Unum est primum et universalissimum principium inter omnia principia formalia". ${ }^{69}$ Each god or divine unity following the first One (Proclus's henads) is also constituted by a unique intention. However, whereas the first One is unum secundum causam principaliformiter, ${ }^{70}$ the divine unities (to which Berthold also refers to as bonitates) are one per essentiam. This difference entails that the gods represent different "contractions" of this first One's unique intention. ${ }^{71}$ The first divine unity (the prime infinitas) is constituted by the intentio infinitatis (or intentio virtutis), the second one (the prime entitas) is constituted by the intentio entitatis, which is a further contraction of the intentio unius, and so on.

69 Berthold of Moosburg, Expositio, 3E, p. 97, l. 214-215. Berthold favours the phrase intentio for describing the nature of the unitates and the prime unum, and tends to reserve principa formalia - that connotes a causal character - for the lower beings composed from several of these intelligible features. Nonetheless, he also uses the latter phrase in the singular form to designate the first One and the unities; see for instance $190 \mathrm{D}, \mathrm{p} .83$, l. 248 .

$70 \quad$ Berthold of Moosburg, Expositio, 5D, p. 120, 1. 248-250.

71 Berthold of Moosburg, Expositio, 43E, p. 71, l. 177-181: [...] rerum sic separatarum quaedam stant in una intentione tantum. Et hoc dupliciter, sive simpliciter, ut prime unum, sive contracte, ut bonitates. Et istae cum prime uno proprie et principaliter dicuntur antipostaton sicut stantes se ipsis totis et totaliter sub absoluta formali independentia ad omnem aliam intentionem. On Berthold's definition of unities or gods, see E. Ludueña, "Dioses, inteligencias y ángeles de Alberto Magno a Bertoldo de Moosburg", in Cuadernos de filosofía 66(2016), p. 47-59. 
Berthold justifies whenever he can his terminology by showing how it fits with Proclus's text, even when his reading does not fully correspond to the intended meaning of the Elementatio. For instance, his reading of the term uniformis given by William of Moerbeke's translation of Proposition 16o ("Omnis divinus intellectus uniformis est" [...]) reverses the original meaning of the

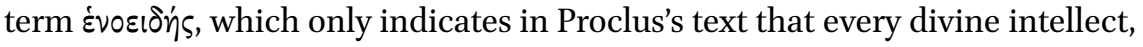
insofar as it is divine, has the character of unity. ${ }^{72}$ Berthold reads this passage as intended to mean that divine intellects share the same formal intention and, to this extent, are essentially identical. ${ }^{73}$ The divine unities sharing the same intention can be called uniform in this sense, which allows Berthold to describe in his own terms the relation between God and the unities. This terminology also supports Berthold's claims on the equivalence of light and form. The gods are constituted by a single formal intention, just like light in the physical realm is the purest form:

Sicut enim lux est maxime formalis et nobilis inter omnes formas sensibiles et habet in se unite et simpliciter et excellenter perfectiones omnium qualitatum visibilium adeo, quod etiam sit hypostasis, id est formalis subsistentia, omnium colorum, ita bonitas deorum consistit in hoc, quod ipsa sola ratione suae supersubstantialitatis est pura et immixta et sic omnino formalis nihil habens vel de materia vel materiae condicionibus sibi permixtum, immo nec de aliis intentionibus formalibus essentialiter. $^{74}$

The single intention defining the unities explains their self-subsistent character. The unities are self-subsistent because they can totally revert upon themselves insofar as they are devoid of any internal complexity and represent different contractions of a unique intention. Berthold's description of the divine beings as formal principles or formal intentions makes the most of

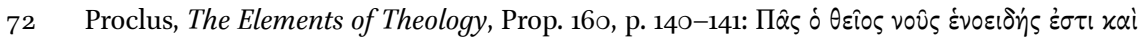

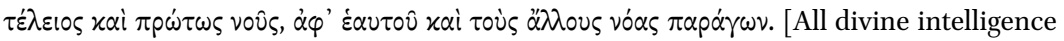
is perfect and has the character of unity; it is the primal Intelligence, and produces the others from its own being - trans. Dodds]. William translates the proposition as follows: Omnis divinus intellectus uniformis est et perfectus et prime intellectus a se ipso alios intellectus producens. See Berthold of Moosburg, Expositio, 16oD, esp. p. 5-6, l. 65-99.

73 Berthold of Moosburg, Expositio, 16oD, p. 5, 1. 75-77: Prime autem et principaliformiter unum, quod est forma superdea, non dicitur proprie 'uniforme', sed 'bonificum' et unificum per commentum 112. Si autem ascribitur sibi nomen 'uniformis', hoc est, inquantum dicitur 'idem' $[\ldots]$.

Berthold of Moosburg, Expositio, 143L, p. 68, 1. 301-308. 
the vocabulary he borrows from Dietrich. Dietrich already used the notions of "intention" and "contractions" in his own account of the emanative process of creation. More precisely, Dietrich employed these notions to conceptualize the emanation of the distinct Intellects from God, each of which instantiates a more or less universal intention (ens, vivum, rationale). ${ }^{75}$ Dietrich described the series of Intelligences flowing from God as a series of contractions of the most formal intention that Dietrich identified with the concept of esse. The term "contraction" meant in this context that the subsequent determinations of this first formal intention are less universal than it. Berthold takes up this terminology, but he adjusts it to the henology of Proclus with its various gods, identifying the more universal and formal intention with the notion of oneness. ${ }^{76}$ As a result, Berthold manages to equate the notions of universality and unity together with the concept of form: whatever is universalius is also actualius and formalius.

\subsection{Composition and Structures of the Formal Intentions}

Berthold's theory of formal principles or formal intentions enables him to offer a mereological account of the way the various ontological layers following the first One are derived from it. According to Berthold's reading of the Elementatio, the realm of specific forms is made up from a combination of the formal intentions constituting the level in between the One and the Intellect. ${ }^{77}$ Below the level of the unitates is the series of the infinitates that are composed of two intentions, namely the intentio infinitatis and the intentio unius (which Berthold also designates as the intentio finitatis due to his identification of the first One and Limit). The subsequent series of the enter entia results from the combination of three formal principles, i.e. the intentio unius, the intentio infinitatis, and the intentio entitatis, and so on.

75 See Dietrich of Freiberg, De intellectu et intelligibili, lib. II, c. 16, §1, p. 157, 1. 28-35: Sicut autem accepimus rationem generis in supremis intellectibus secundum primam et simplicissimam omnium intentionum entis, scilicet secundum esse, sic sumendum est rationem speciei secundum quandam intentionem magis contractam et minus simplicem in his, quae sequuntur inferius, scilicet in intellectibus moventibus caelos, et haec intentio est vivum inquantum vivum. In ipsis enim primo invenitur ratio vitae quantum ad moventia et mota, et ideo haec intentio formalis secundo loco ponitur et immediate post primam omnium intentionum, scilicet ipsum ens, cui mox coordinatur vivum.

76 On the conceptual shifts entailed by Berthold's henology, see E. King, "Berthold of Moosburg on Intellect and the One of the Soul", in Dionysius 36(2018), p. 184-199.

77 Berthold of Moosburg, Expositio, 43E, p. 71, l. 182-183: Quaedam vero stant in pluribus intentionibus. Et hoc dupliciter, quia vel habent respectu ad corpus vel non. 
It must be noted that Berthold attempts a mathematico-metaphysical deduction of the numbers of divine beings and highest spiritual entities in general. In doing so, Berthold demonstrates a certain familiarity with Boethius's De institutione arithmetica, which conveyed the Platonist and Pythagorean theories of Nicomachus of Gerasa whose reincarnation, as the story goes, Proclus was believed to be. Berthold establishes that the first multiplicity must be such that it can be divided into three parts, since every essentially ordered series includes a beginning, a medium, and an end. The first multiplicity - the divine unities - must be composed of six elements, since it is the least number than can be decomposed in three equal parts (given that the number 3 can only be divided in three elements than are not quantities but three unities). ${ }^{78}$ The number six - the first perfect number ${ }^{79}$ - allows the first multiplicity to be divided into equal parts following an arithmetical proportion. This arithmetic proportion, unlike other types of proportion (geometric, harmonic), preserves the same difference between the terms of the series and, therefore, expresses in spite of this difference their essential identity (identitas unius intentionis). ${ }^{80}$ On the basis on such principles, Berthold deduces the number of the subsequent series of principles (infinitates, enter entia, vitae, and so on) that result from the first series of unities and the different combinations of formal principles received from them. ${ }^{81}$

We can see now how specific forms constituting the intelligible models of concrete individuals result from a composition of principia formalia that ultimately stem from the first contractions of the intentio unius. Although it is unique, the substantial form inhering in a compound substance is made up of different formal principles that can be analyzed through its essential definition. Berthold's characterization of the formalia principia as partes ante totum (parts of the specific definition) complexifies the Proclean notion of a "whole

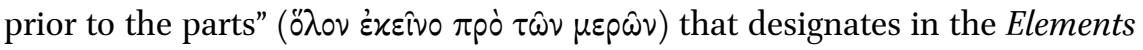
the first cause of a series of beings depending on it. But this theory of formal intentions allows Berthold to conceptualize the internal complexity of specific forms and to relate it to their ultimate intelligible causes. To this extent, the formal intentions or formal principles are the fundamental elements of the various degrees of composition present in the cosmological order. This expansion of the hylomorphic terminology enables Berthold to analyze the

78 Berthold of Moosburg, Expositio, 62B, p. 182, l. 61-64.

79 Berthold of Moosburg, Expositio, 62B, p. 182, l. 40.

8o Berthold of Moosburg, Expositio, 62B, p. 183, l. 82.

81 See the table in the CРтMA edition, Expositio, 62B, p. 184. 
whole hierarchy of beings in terms of formal composition - something alien to Proclus's Elementatio in which forms are described as mutually intricated at the intellectual level. ${ }^{82}$ As recent studies have shown, Berthold makes the most of this mereological account of formal principles through which he bridges theological sources quite distant from a terminological point of view (most notably Eriugena's doctrine of the primordial causes). ${ }^{83}$

One of the most interesting aspects of Berthold's theory of formal principles lies in the fact that he intends not only to use it to explain the constitution of specific essences but also the emergence of material reality. Indeed, Berthold deduces from the different ways the formal principles can be connected the three main classes of beings composing the whole universe. The first class comprises formal principles that can be associated with one another at a formal level to constitute specific essences. For the second class, due to a certain degree of complexity, the composition of formal principles does not generate unified essences but results in different natures, producing the sphere of bodies (corpora). The process by which the composition of formal principles comes to produce material beings is described as a "distraction" (in contrast with contraction) from their own nature of principles. Whereas the formal principles can combine in a unified and stable manner to produce purely intelligible beings (the entia secundum speciem), the increasing complexity of their composition generates natures that become separate from their intelligible models and are affected by the multiplicity characterizing the sensible world. In accordance with the principle of continuity, a third class must exist where the formal intentions produce realities affected by division but still participating to the intellectual level, that is to say souls. ${ }^{84}$ In some cases, Berthold further details this scale of being. He explains how the celestial souls are located in between the celestial bodies and the incorporeal beings which, inasmuch as they are defined by a plurality of formal principles, still remain under the divine unities consisting in one unique intention:

'Hoc autem medium necessario triplex, unum quidem per aequidistantiam et duo per approximationem extremorum'. Illud autem medium, quod est superiori extremo proximum, est omnis res per se perfecta, in qua principia formalia remanent in ratione et natura principiorum

\footnotetext{
82 Proclus, The Elements of Theology, Prop. 176, p. 154-155.

83 Ludueña, La recepción de Eriúgena en Bertoldo de Moosburg. On Eriugena's influence on Berthold, see also King, "Eriugenism in Berthold of Moosburg".

84 See also Berthold of Moosburg, Expositio, 34D, p. 229-23o, l. 325-329; 76I, p. 69-70, l. 178192; 8oC, p. 100-101, l. 64-73; 91B, p. 159, l. 41-46; 108E, p. 4-5, l. 59-71; 171A, p. 109, l. 14-121; 187 E, p. 51, l. 264-267; 197B, p. 134, l. 50-54.
} 
simpliciter, et per consequens sunt res ut simpliciter et secundum speciem. Medium vero, quod est inferiori extremo proximum, est substantia corporis caelestis, in quo, licet sit incorruptibile, tamen principia formalia sunt in ea simpliciter distracta in ulteriores naturas, scilicet in naturam corporeitatis, et sic est res ut haec et particularis, hoc, inquam, medium est immediatum generabilibus et corruptibilibus. Est et medium per aequidistantiam, in quo principia formalia nec remanent simpliciter in ratione et natura principiorum nec etiam simpliciter distrahuntur in alias naturas, puta anima totalis, quae est separata, et sic communicat superioribus, et coniuncta corpori, et sic communicat cum inferioribus propter respectum ad corpus, a quo superiora sunt penitus absoluta. 'Et sic omnia sunt conexa in virtute, quam conexionem Pythagoras vocavit catenam auream. ${ }^{85}$

Thus, Berthold maintains the key standpoints of Dietrich's ontology, and manages to take into account with the same conceptual architecture the level of divine beings that Dietrich did not take into account. To this extent, Berthold intimately links the core intuition of his emanative model with precise stances on contemporary issues, like the status of quantified matter in the process of individuation and the thesis of the unicity of form in human beings. These positions are articulated through a dynamic conception of essences, which flow from the ideal sphere to the physical realm in multiple modes of being.

\subsection{The Status of Forms in Matter}

The resemblance or dissemblance between the terms of the chain of being can now be explained within this extended hylomorphic framework. Although a formal cause usually accounts for the resemblance between the cause and its effect, since it consists in the transmission of the same essence from one subject to another, this transmission can happen more or less perfectly. According to Berthold, perfect resemblance exists when two things share the same form according to the same reason and mode, like the Father and the Son. A less perfect resemblance exists when two things share the same form according to the same reason but not the same mode, and a still less perfect when they share the same form but neither according to the same reason nor the same mode. ${ }^{86}$ To explain these different modalities in the transmission of a same form, Berthold uses again the notion of formal intentions along with the couple contraction/distraction. Every agent brings about something similar to itself.

85 Berthold of Moosburg, Expositio, 108E, p. 4-5, l. 59-73.

86 Berthold of Moosburg, Expositio, 28D, p. 177, l. 171-177. 
However, insofar as it does so by transmitting a certain formal intention, this intention sometimes remains the same, whereas it is sometimes contracted or even "distracted" into other natures, accounting for the various degrees of multiplicity that reaches its highest point in the material world. ${ }^{87}$

However, since they derive from a combination of principia formalia, forms possess an intrinsic relation to their intelligible models even at the lowest level of matter. On this point, Berthold's theory of material forms is indebted to Albert the Great's views on the subject, which he follows closely. In Albert's system, the theory of natural generation was based on a certain conception of matter, according to which forms somehow already exist in it, even if under a potential mode of being called incohatio formae. Interestingly, Albert analyzed the structure of matter with the same concepts serving to define emanative causality in general, namely the idea of identity secundum essentiam and difference secundum esse. ${ }^{88}$ According to Albert, forms as such are essentially identical with their privation in matter. They remain essentially unchanged when actualized in it, and only change according to their being. In his Metaphysica, this theory was intended to solve the problem of the emergence of natural beings. It explains how new forms can arise in nature without having to admit their preexistence in matter and without postulating their induction ab extra by God. ${ }^{89}$ The idea of an active potency of matter is in line with the principle according to which nothing comes from nothing. It also entails that matter already contains the disposition for future actualizations. Albert called this potency aptitudo formalis and equated it with the concept of rationes seminales. ${ }^{90}$

Dietrich of Freiberg also subscribed to the thesis that potential forms in matter are identical secundum essentiam with actual forms, although distinct from them secundum esse. In his treatise De miscibilibus in mixto, Dietrich took

87 Berthold of Moosburg, Expositio, 28E, p. 177, l. 231-235.

88 Albert's theory of matter, along with its associated concepts of active potency and the incohatio formae, is disseminated among different works (for instance Physica, lib. I, tr. 3, c. 10; De anima, lib. I, tr. 2, c. 7; De caelo, lib. I, tr. 3, c. 4) has been studied in detail, beginning with Nardi's works (see esp. B. Nardi, "La dottrina d'Alberto Magno sull' inchoatio formae", in Studi di filosofia medievale (1960), p. 69-101). For a recent synthesis on the topic, see A. Rodolfi, Il concetto di materia nell'opera di Alberto Magno (Firenze: Galluzzo, 2004).

89 Albert the Great, Metaphysica, lib. XI, tr. 1, c. 8, p. 468-471.

90 See P.M. Wengel, Die Lehre von den rationes seminales bei Albert dem Grossen: Eine terminologische und problemgeschichtliche Untersuchung (Würzburg: Mayr, 1937); Nardi, "La dottrina d'Alberto Magno sull' inchoatio formae". 
care to specify that this idea does not entail the plurality of forms in matter, an apparent consequence of this thesis. ${ }^{91}$

Differentiating the equivocal meanings of the phrase "active potency", 92 Berthold equally conceives the essentia formae as something permanent receiving different modes of being, and takes up the notion of incohatio formae..$^{93}$ Like Dietrich, Berthold refuses the separability of matter from form as much as the plurality of forms and, like Albert, he does not make use of the literal interpretation of the Dator formarum attributed by Albert to the Platonici. ${ }^{94}$ The most notable aspect of his position lies in his insistence on the intimate connection between the potential being of forms in matter and their intelligible model. The form understood as the ideal model eternally existing at the intellectual level is the constitutive principle of a thing's essence (principium constitutivum esse specifici), even for something like a house that is brought to being artificially. ${ }^{95}$ In this respect, specific essences enjoy an eternal mode of being in the divine intellect that is independent of their contingent actualization in the material world. ${ }^{96}$ Commenting on Proposition 48, Berthold states more precisely in which sense forms are eternal. He demonstrates that the

91 Dietrich of Freiberg, Tractatus de miscibilibus in mixto, ed. W. Wallace (Hamburg: Meiner, 1985), 21, p. 46-47.

92 On the notion of potentia activa, see ${ }_{25} \mathrm{C}, \mathrm{p} .141-142$, where Berthold distinguishes three types of active potency, which enables him to deduce three maneries perfectorum. See also Berthold, Expositio, 78A-E, p. 86, l. 21-25; p. 89, l. $109-122 ; 27$ E, p. 165, l. 144-154. Let us note that in Proposition $1 B$, Berthold defines the potential plurality of forms in matter as a "passive potential multitude" (Berthold, Expositio, 1B, p. 74-75, l. 129-135).

93 See Berthold of Moosburg, Expositio, 77G, p. 78, 1. 158-164: Forma etiam dicitur esse in potentia in materia, inquantum essentia sua stans sub esse imperfecto seu potentiali, quod quidam vocant esse confusi habitus, perficitur in actum existentem eiusdem essentiae cum forma in potentia. Potentia enim et actus non diversificant essentiam formae, hoc est forma in potentia et in actu non diversificant eandem numero essentiam, cum processus de potentia ad actum non largiatur procedenti multitudinem essentiarum, sed perfectionem in esse et in toto. See also Berthold, Expositio, 24A, p. 126, l. 45-47; 59 C, p. 167, l.153-154, l. 162-163; 205A-C, p. 209, l. 23-30. On the implications of this position in Berthold's emanationist metaphysics, see M.R. Pagnoni-Sturlese, "À propos du néoplatonisme d'Albert le Grand. Aventures et mésaventures de quelques textes d'Albert dans le Commentaire sur Proclus de Berthold de Moosburg", in Archives de philosophie 43(1980), p. 635-654, esp. p. 635-638.

94 Albert the Great, De causis et processu universitatis a prima causa, lib. I, tr. 4, c. 1, p. 43-44.

95 Berthold of Moosburg, Expositio, 178F, p. 197, 1. 285-292.

96 Berthold of Moosburg, Expositio, 118B, p. 77, l. 63-66: Sed res ab aeterno fuerunt in Dei omnipotentia et voluntate tantum secundum esse potentiale potentiae activae, in scientia fuerunt ab aeterno non solum ut in potentia causae secundum illam speciem scientiae Dei, quae vocatur dispositio, sed etiam quia, ut dictum est supra, rerum rationes ab aeterno sunt in ipsa. 
corruption of an individual form - even a corporeal one - does not annihilate its entire being. The true form as such - the ideal model from which an individual is brought to actual existence - never ceases to subsist as an essence, even if it can lose existence ("nulla forma substantialis cadit ab essentia in purum non ens, licet quaedam cadant ab esse"). ${ }^{97}$ To this extent, Berthold's theory of generation of natural forms at the lowest level of matter is intrinsically dependent on his doctrine of universals since it implies the thesis of a variation of the same essence only secundum esse.

\subsection{Berthold's Classifications of Forms}

From all of these concepts, Berthold is able to describe the structure of the Proclean universe in his own terms - that is to say, without abandoning the vocabulary of forms inherited from the Latin theological tradition. Thus, the structure of the multiple modes of being is not simply repeated from the descriptions given by the Elements, but it is thoroughly analyzed and justified through Berthold's conceptual framework. Berthold offers several classifications of forms that all underline the principle of continuity 98 according to which between any two opposite orders of beings, something must always exist. ${ }^{99}$ While the divine unities only contain a unique formal intention, the realm of specific forms begins at the intellectual level and, from there, covers the entirety of the created universe. Commenting on Proposition 41, Berthold defines a purely spiritual being as a forming form (forma formans), whereas a form having a relation to matter is a forma informans. Forming forms are per subsistens, whereas informing forms subsist per aliud, due to their relation to matter. The class of informing forms is subdivided in corporeal and non-corporeal. It covers the entire range of forms that are not entirely intellectual, from souls - be they total or partial - to purely corporeal forms. Forming forms, on their side, can be divided due to the fact that some of them function like subjects for others, even if not in a material sense, since they are composed from different formal intentions. Indeed, some forming forms are

97 Berthold of Moosburg, Expositio, 48B, p. 97, 1. 121-133.

98 On this point, see also Berthold, Expositio, 205A, p. 209, 1. 20-22 where Berthold distinguishes three modes of information following a similar reasoning.

99 These classifications are often redundant but nonetheless present the interest of being based on different approaches that encompass Berthold's theory of formal principles and maneries entium. The main examples can be found in Proposition 25 (following the modalities of constitution, p. 142-143); Proposition 41 (types of informing relations, p. 49-51); Proposition 48 (relation to privation, p. 94-96); Proposition 82 (criterion of divisibility, p. 118-119); Proposition 112 (separability, p. 28-29); Proposition 173 (participation, p. 129-130); Proposition 190 (operations, p. 83-84); Proposition 205 (relation to matter, p. 209-210). 
more universal than another because they are composed of fewer intentions (as stated in Proposition 72). This distinction, therefore, supposes Berthold's theory of the composition from formal intentions that defines the dependence relations among the highest realities. ${ }^{100}$

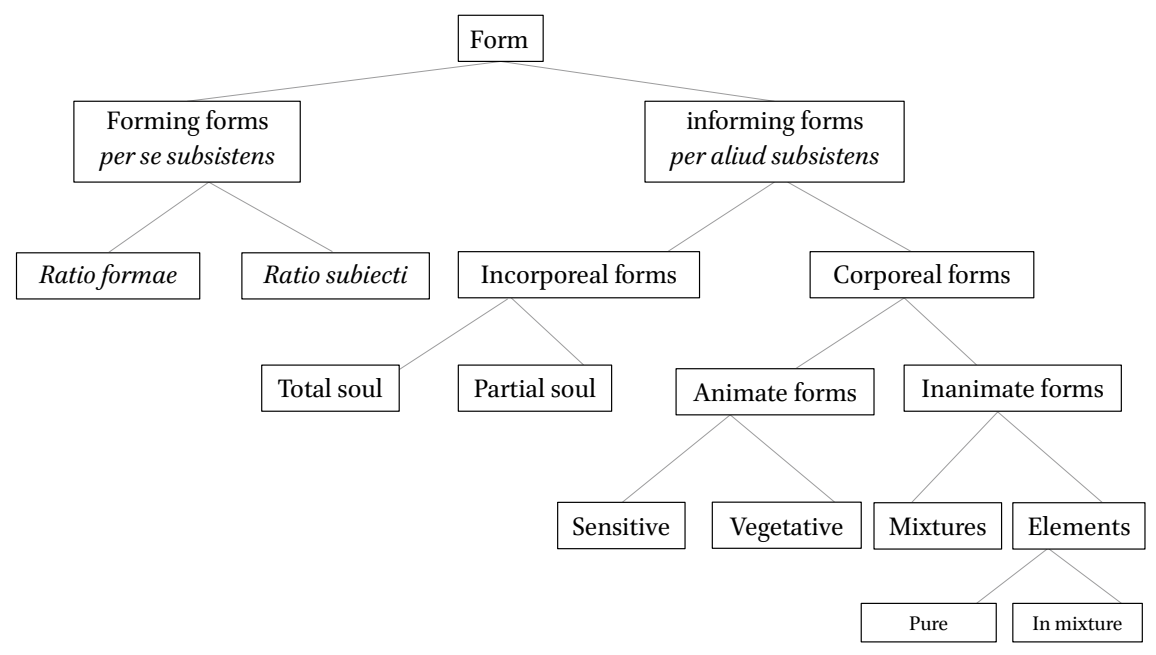

100 Berthold of Moosburg, Expositio, 41C, p. 49-51, l. 73-148: Ex praemissis evidenter apparet, quod subsistere per se et non fulciri aliquo alio, et esse in alio sive fulciri et sustentari aliquo alio sunt modi substantiae ita, quod omnis forma formans habet subsistentiam per se, informans autem habet esse in alio, quae etiam, ut sit in genere dicere, est duplicis maneriei: quaedam enim est corporalis, quaedam non, seu incorporalis. Dico autem 'corporales', quae educuntur de potentia materiae per agens physicum. Et haec adhuc sunt in duplici differentia, quia vel sunt formae animatorum vel inanimatorum, et haec sunt generum diversorum, quia vel elementorum vel mixtorum [...]. Formae autem animatorum corporales etiam sunt in duplici differentia, quia vel vegetabilium vel sensibilium. [...] Super quam sunt formae simpliciter incorporales, et hae iterum sunt in duplici manerie, quia vel partiales vel totales. Partialis autem est anima rationalis, quae inquantum huiusmodi non est actus alicuius corporis neque forma corporalis nec operans in corpore, sed solum inquantum est vegetativa [...]. Totalis autem, quae etiam nobilis anima dicitur, secundum se totam est elevata super corpus subiectum, licet etiam secundum se totam sit in corpore, quamvis autem secundum aliam et aliam rationem. Et ista tenet ultimum seu supremum gradum formarum informantium. Ex praemissis apparet, qualiter formae informantes habeant esse in. Verum, quia in formis formantibus quibusdam, non inquantum sunt formantes, sed formatae, compositis videlicet ex diversis intentionibus pluribus vel paucioribus, quales sunt omnes res supra animas totales et citra bonitates existentes, quaedam habent rationem subiectorum, quaedam autem formarum, ideo etiam tales quasiformae insunt suis subiectis, cum quibus tamen non ponunt in numerum essentiarum sicut informantes praedictae, sed compositum ex eis est ut res una, quae est ens ut simpliciter et secundum speciem. 
Some differences in these classifications must be noted, however. For instance, the principle of continuity is sometimes intended to define the status of human souls, which are partly informing matter, and partly detached from it by their intellectual character. This is the case in Proposition 82, where Berthold analyzes the multiplication of forms in matter and classifies them according to division or partibility. Forms can be grouped into two general classes: those that can be divided according to their subject, and those that are fully separate from matter. In the former group, there exists a distinction between entia secundum speciem like hypostatic intelligences and particular beings like angels. ${ }^{101}$ Among the forms that can be divided according to their subject, some are fully immersed in matter, whereas others are totally undivided by their subject and remain separate from it, like celestial forms (total souls).102 According to the principle of continuity, human souls are then defined in between incorporeal forms not divided by their subject and forms entirely divided by it. 103

At other places, like in Proposition 112, the principle of continuity is rather meant to clarify the status of total or celestial souls. Here, Berthold presents the gradation of forms following the criterion of separability. ${ }^{104}$ Total souls are presented as formae mediae, i.e. located between the realm of incarnate forms and purely separate entities. Berthold explains that total souls are only causes and not principles since they are not educed from potency to act, unlike material forms that are both principles and causes. Natural forms present different degrees of separability from matter, from the most humble souls entirely immersed in it to the rational souls whose intellectual activity does not depend on matter. Fully separate forms can be divided due to the fact that some selfsubsistent entities are still inferior to the level of gods which, unlike the first One, include a first type of multiplicity. Berthold complements this classification with the Boethian distinction between the true forms, entirely separated from matter, and the imagines formarum..$^{105}$

\footnotetext{
101 Berthold of Moosburg, Expositio, 82A, p. 118, l. 17-18.

102 Berthold of Moosburg, Expositio, 82A, p. 119-120, l. 69-71: Non enim existunt ex eo neque in parte et universaliter neque in divisibili neque in indivisibili, et istae sunt formae, quae sunt quasi extremae ad formas corporales.

103 Berthold of Moosburg, Expositio, 82A, p. 120, l. 77-78.

104 Berthold of Moosburg, Expositio, 112D, p. 28, 1. 114-119: Inter veras vero formas et non veras, quia sunt extremae, necessario dantur formae mediae, scilicet animae caelorum, quae conectunt causaliter infimas cum supremis. Ex praemissis apparet formae diversa significatio, quia dicitur et de forma thearchica et principaliformi per se et secundum se subsistente, quae sunt verae formae, et de non veris secundum suos gradus et mediis inter extremas.

105 Berthold of Moosburg, Expositio, 112D, p. 28, l. 105, l. 122.
} 


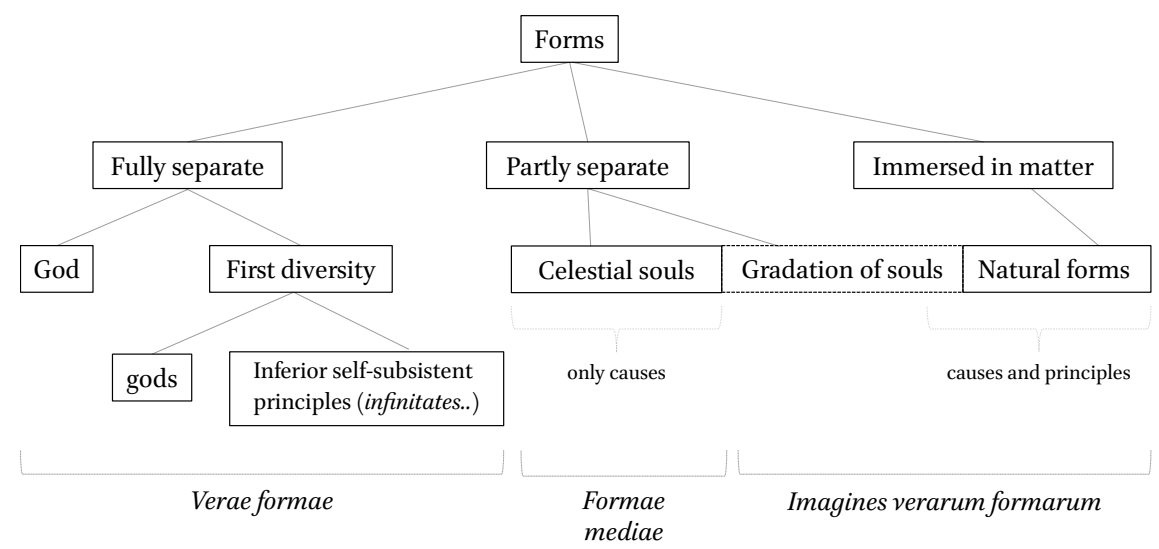

In Proposition 48, Berthold offers another description of the hierarchy of forms based on the way they relate to privation and potency. ${ }^{106}$ Here, this approach enables him to provide a classification that takes into account the way different kinds of forms exist or come to being. Purely corporeal forms such as the elements or material bodies are subject to privation secundum subiectum et formam, because these forms are entirely educed from the potency of matter and, like the composite substance in which their inhere, did not exist before this actualization. ${ }^{107}$ The operations of such entities are entirely dependent on their bodies. Other forms, like partial souls, are partly separable from their subject since some of their activities (intellectual operations) are independent of matter. These forms, therefore, cannot be not educed from the potency of matter and, because of that, do not cease to exist when separated from their subject. ${ }^{108}$ A third kind of forms, the total souls, is neither separable nor subject to annihilation. ${ }^{109}$

106 Berthold of Moosburg, Expositio, 48A, p. 94-96, l. 17-98.

107 Berthold of Moosburg, Expositio, 48A, p. 94, l. 21-24: Omnes enim tales formae habent privationem oppositam secundum subiectum et formam, quia totum, quod fit actu, fuit prius in potentia; compositum autem fit actu; ergo et quantum ad materiam et formam prius fuit in potentia.

108 Berthold of Moosburg, Expositio, 48A, p. 94, 1. 25-28: Alia est forma habens privationem secundum subiectum et non secundum se ipsum, qualis est anima partialis: non enim educitur de potentia materiae, sed corpore organizato secundum Aristotelem infunditur, propter quod etiam non tota immergitur, sed partim est separata.

109 Berthold of Moosburg, Expositio, 48A, p. 96, l. 93-98. 


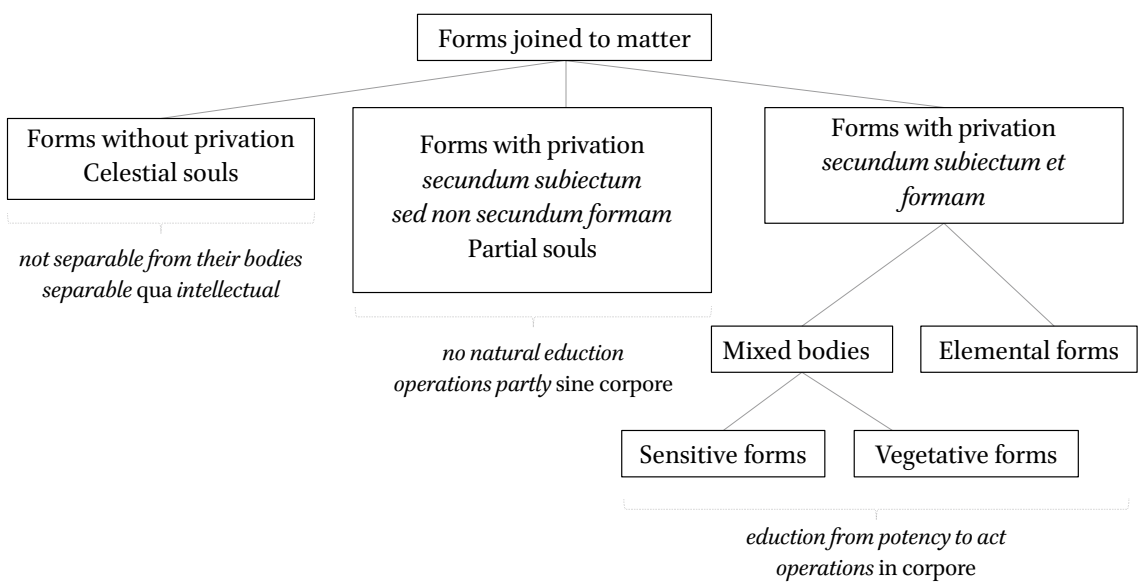

It appears that these classifications use different criteria to demarcate the dynamic, modal, and relational aspects of a same graduated structure. Despite slight differences owing to the criteria taken into account, the classifications are convergent. They show how Berthold manages to conceptualize the complex organization of the Proclean universe in his own terms, obtaining a sort of combinatory deduction of the main ontological levels exposed in the Elementatio.

\section{Conclusion}

In view of these elements, Berthold's main innovations on the theme of forms appear as complementary aspects of a same project, i.e. to found his doctrine of emanation within the philosophical vocabulary of his time despite the dominance of Aristotelian hylomorphism. His efforts to provide a rigorous definition of light in its spiritual dimension, to justify its status as a universal principle and to explain its different modalities of manifestation all work toward the same goal, that we could sum up in the expression "metaphysics of light". The concept of light and its generative dynamism enables Berthold to sharpen Albert's distinction between the Aristotelian conception of formal causation and the specific action of the formal flux. The diffusing action of the first cause in different modes of manifestation is conceptualized as the multiplication and diffraction of a primordial formal principle, which virtually contains the different intentions composing the created universe, just as natural light - invisible in itself - contains all possible colors. 
To explain the mix of identity and otherness entailed by this diffusion, Berthold draws on the key idea that something can produce an effect essentially identical to the cause but different secundum esse. Even though Berthold does not depart on this point from the main positions of his Dominican predecessors, his own contribution extends these ideas to a more complex universe that, in addition, was not theorized in the same concepts in the Elements. This conceptual adaptation relies on a twofold strategy. On the one hand, Berthold selects and extends several technical notions inherited from the German Dominican School to make sense of different aspects of Proclus's text. This is true of Dietrich's theory of perfectional forms that helps to describe the dynamic aspect of the flux, whose action is simple and instantaneous like the operations of agents acting per essentiam. This same goes for the concepts of intentio formalis or principium formale, that Berthold employs to study a level of reality (i.e. gods or divine unities) that his predecessors did not recognize. On the other hand, Berthold applies the conceptual framework of hylomorphism already available to him (idea, species, forma) to organize the layers of reality owing to a small set of additional terms (forma formans, formans informans, forma subsistens, forma per se/per aliud subsistens, and so on). In his innovations, Berthold remains faithful to the fundamental ideas defended by his Dominican masters about the unity of the hylomorphic compound, the status of matter and the nature of causality.

Alain de Libera has considered one of the central ideas of the School of Cologne to be the model of causation based on the idea of a formal flux that, through different modes of being, remains essentially the same. ${ }^{110}$ To a certain extent, some may wonder if this model would apply to Berthold's theory of forms itself when compared to the foundations laid by his predecessors. The originality of his construction lies in the unique way he combines multiple sources, even when his main authorities were openly hostile to them, like Albert the Great was hostile to Ibn Gabirol. On the theme of forms and formal causation, Berthold departs on several points from his main influences, notably Albert and his Dominican followers. But it would be a mistake to see his innovations as a betrayal of them, when Berthold is first driven by the unparalleled will to explain the full complexity of Proclus's work in the philosophical vocabulary of his time.

110 De Libera, La mystique rhénane, p. 361. 


\section{Bibliography}

\section{Primary Sources}

Adam Pulchrae Mulieris, Liber de intelligentiis, in C. Baeumker (ed.), Witelo, ein Philosoph und Naturforscher des XIII. Jahrhunderts, Münster i.W., Aschendorff, 1908, p. 1-71.

Albert the Great, Metaphysica, ed. B. Geyer, Münster i.W., Aschendorff, 196o.

Albert the Great, Physica, ed. P. Hossfeld, Münster i.W., Aschendorff, 1987.

Albert the Great, De causis et processu universitatis a prima causa, ed. W. Fauser, Münster i.W., Aschendorff, 1993.

Albert the Great, Super Porphyrium de V Universalibus, ed. M. Santos Noya, Münster i.W., Aschendorff, 2004.

Augustine, De diversis quaestionibus octoginta tribus, ed. A. Mutzenbecher, Turnhout, Brepols, 1975 .

Avicebron, Fons vitae. Translationem ex Arabico in Latinum, ed. C. Baeumker, Münster, Aschendorff, 1892-1895.

Berthold of Moosburg, Expositio super Elementationem theologicam Procli. Prologus. Propositiones 1-13, eds M.R. Pagnoni-Sturlese, L. Sturlese, Hamburg, Meiner, 1984.

Berthold of Moosburg, Expositio super Elementationem theologicam Procli. Propositiones 14-34, eds L. Sturlese, M.R. Pagnoni-Sturlese, B. Mojsisch, Hamburg, Meiner, 1986.

Berthold of Moosburg, Expositio super Elementationem theologicam Procli. Propositiones 35-65, ed. A. Sannino, Hamburg, Meiner, 2001.

Berthold of Moosburg, Expositio super Elementationem theologicam Procli. Propositiones 66-107, ed. I. Zavattero, Hamburg, Meiner, 2003.

Berthold of Moosburg, Expositio super Elementationem theologicam Procli. Propositiones 108-135, ed. F. Retucci, Hamburg, Meiner, 2011.

Berthold of Moosburg, Expositio super Elementationem theologicam Procli. Propositiones 136-159, ed. F. Retucci, Hamburg, Meiner, 2007.

Berthold of Moosburg, Expositio super Elementationem theologicam Procli. Propositiones 16o-183, eds U.R. Jeck, I.J. Tautz, Hamburg, Meiner, 2003.

Berthold of Moosburg, Expositio super Elementationem theologicam Procli. Propositiones 184-211, ed. L. Sturlese, Hamburg, Meiner, 2014.

Dietrich of Freiberg, Opera omnia, vol. ı. Schriften zur Intellekttheorie, ed. B. Mojsisch, Hamburg, Meiner, 1977.

Dietrich of Freiberg, Opera omnia, vol. 2. Schriften zur Metaphysik und Theologie, eds R. Imbach et al., Hamburg, Meiner, 198o.

Dietrich of Freiberg, Opera omnia, vol. 3. Schriften zur Naturphilosophie und Metaphysik, eds J.-D. Cavigioli et al., Hamburg, Meiner, 1983.

Dietrich of Freiberg, Opera omnia, vol. 4. Schriften zur Naturwissenschaft, Briefe, eds M.R. Pagnoni-Sturlese et al., Hamburg, Meiner, 1985. 
Liber de causis - A. Pattin, "Le Liber de causis. Édition établie à l'aide de 90 manuscrits avec introduction et notes", in Tijdschrift voor Filosofie 28(1966), p. 90-203; repr. in A. Pattin, Miscellanea. I. Liber de causis, Leuven, Bibliotheek van de Faculteit der Godgeleerdheid, 2000.

Proclus, The Elements of Theology, ed. E.R. Dodds, Oxford, Oxford University Press, 1971. Ulrich of Strassburg, De summo bono. Liber 1, ed. B. Mojsisch, Hamburg, Meiner, 1989.

Ulrich of Strassburg, De summo bono. Liber 2, Tractatus 1-4, ed. A. de Libera, Hamburg, Meiner, 1987.

Ulrich of Strassburg, De summo bono. Liber 2, Tractatus 5-6, ed. A. Beccarisi, Hamburg, Meiner, 2007.

Ulrich of Strassburg, De summo bono. Liber 3, Tractatus 1-3, ed. S. Tuzzo, Hamburg, Meiner, 2004.

Ulrich of Strassburg, De summo bono. Liber 3, Tractatus 4-5, ed. S. Tuzzo, Hamburg, Meiner, 2007.

Ulrich of Strassburg, De summo bono. Liber 4, Tractatus 1-2,7, ed. S. Pieperhoff, Hamburg, Meiner, 1987.

Ulrich of Strassburg, De summo bono. Liber 4, Tractatus 2,8-14, ed. A. Palazzo, Hamburg, Meiner, 2012.

Ulrich of Strassburg, De summo bono. Liber 4, Tractatus 2,15-24, eds B. Mojsisch, F. Retucci, Hamburg, Meiner, 2008.

Ulrich of Strassburg, De summo bono. Liber 4, Tractatus 3, ed. A. Palazzo, Hamburg, Meiner, 2005.

Ulrich of Strassburg, De summo bono. Liber 6, Tractatus 1-3,6, ed. S. Tuzzo, Hamburg, Meiner, 2011.

Ulrich of Strassburg, De summo bono. Liber 6, Tractatus 3,7-29, ed. S. Ciancioso, Hamburg, Meiner, 2015.

Ulrich of Strassburg, De summo bono. Liber 6, Tractatus 4,1-15, eds I. Zavattero, C. Colomba, Hamburg, Meiner, 2017.

\section{Secondary Sources}

Bertolacci, A., "Le citazioni implicite testuali della Philosophia prima di Avicenna nel Commento alla Metafisica di Alberto Magno: analisi tipologica", in Documenti e Studi sulla Tradizione Filosofica Medievale 12(2001), p. 179-274.

Bonin, T.M., Creation as Emanation, The Origin of Diversity in Albert the Great's On the Causes and Procession of the Universe, Notre Dame, Notre Dame University Press, 2001.

Faës de Mottoni, B., "Il problema della luce nel Commento di Bertoldo di Moosburg all'Elementatio theologica di Proclo. Edizione delle proposizione riguardante il tempo e l'eternità", in Studi medievali 16(1975), p. 325-352. 
Flasch, K., "Procedere ut imago. Das Hervorgehen des Intellekts aus seinem göttlichen Grund bei Meister Dietrich, Meister Eckhart und Berthold von Moosburg”, in K. Ruh (ed.), Abendländische Mystik im Mittelalter, Stuttgart, Metzler, 1986, p. 125-134.

Flasch, K., "Einleitung", in Dietrich of Freiberg, Schriften zur Naturphilosophie und Metaphysik, p. XV-XXXI.

King, E., "Berthold of Moosburg on Intellect and the One of the Soul", in Dionysius 36(2018), p. 184-199.

King, E., "Eriugenism in Berthold of Moosburg's Expositio super Elementationem theologicam Procli", in D. Calma (ed.), Reading Proclus and the Book of Causes. Vol. 1. Scholarly Networks and Debates, Leiden, Brill, 2019, p. 394-437.

Lang, H.S., "The Status of Body in Proclus", in D.D. Butorac, D.A. Layne (eds), Proclus and his Legacy, Berlin / Boston, De Gruyter, 2017, p. 69-82.

Lescoe, F.J., God as First Principle in Ulrich of Strasbourg: Critical text of Summa de bono, IV, 1, New York, Alba House, 1979.

Libera, A. de, "La problématique des intentiones primae et secundae chez Dietrich de Freiberg”, in K. Flasch (ed.), Von Meister Dietrich zu Meister Eckhart, Hamburg, Meiner, 1984, p. 68-94.

Libera, A. de, "Ulrich de Strasbourg, lecteur d'Albert le Grand", in Freiburger Zeitschrift für Philosophie und Theologie 32(1985), p. 105-136.

Libera, A. de, La mystique rhénane, d'Albert le Grand à Maître Eckhart, Paris, Seuil, 1994. Libera, A. de, La querelle des universaux. De Platon à la fin du Moyen Âge, Paris, Seuil, 1996.

Libera, A. de, Métaphysique et noétique: Albert le Grand, Paris, Vrin, 2005.

Ludueña, E., La recepción de Eriúgena en Bertoldo de Moosburg: Un aporte sobre la Escuela de Colonia, Saarbrücken, Publicia, 2013.

Ludueña, E., "Creatio y determinatio en la Escuela Renana: de Alberto Magno a Bertoldo de Moosburg”, in Princípios: Revista de Filosofia 22/37(2015), p. 77-97.

Ludueña, E., "Dioses, inteligencias y ángeles de Alberto Magno a Bertoldo de Moosburg”, in Cuadernos de filosofía 66(2016), p. 47-59.

Maier, A., Die Vorläufer Galileis im 14. Jh., Roma, Edizioni di Storia e Letteratura, 1949.

Maier, A., Zwischen Philosophie und Mechanik, Roma, Edizioni di Storia e Letteratura, $195^{8}$.

McGinn, B., "Ibn Gabirol, The Sage among the Schoolmen", in L.E. Goodman (ed.), Neoplatonism and Jewish Thought, Albany, State University of New York Press, 1992, p. $77-110$.

Milazzo, S., La théorie du fluxus chez Albert le Grand. Principes philosophiques et appliA cations théologiques, PhD diss., Université de Metz, 2007 < URL:https://hal.univlorraine.fr/tel-o1749027/document>.

Nardi, B., "La Dottrina d'Alberto Magno sull' inchoatio formae", in Studi difilosofia medievale (1960), p. 69-101. 
Noone, T., "Albert and the Triplex universale", in I.M. Resnick (ed.), A Companion to Albert the Great. Theology, Philosophy and the Sciences, Leiden / Boston, Brill, 2013, p. 619-626.

Pagnoni-Sturlese, M.R., “À propos du néoplatonisme d'Albert le Grand. Aventures et mésaventures de quelques textes d'Albert dans le Commentaire sur Proclus de Berthold de Moosburg", in Archives de philosophie 43(1980), p. 635-654.

Pagnoni-Sturlese, M.R., "Filosofia della natura e filosofia dell'intelletto in Teodorico di Freiberg e Bertoldo di Moosburg", in K. Flasch (ed.), Von Meister Dietrich zu Meister Eckhart, Hamburg, Meiner, 1984, p. 115-127.

Paschetto, E., "L'Elementatio theologica di Proclo e il Commento di Bertoldo di Moosburg. Alcuni aspetti della nozione de causa", in Filosofia 27(1976), p. 353-378.

Pessin, S., Ibn Gabirol's Theology of Desire: Matter and Method in Jewish Medieval Neoplatonism, Cambridge, Cambridge University Press, 2013.

Putnam, C., "Ulrich of Strasbourg and the Aristotelian Causes", in J.K. Ryan (ed.), Studies in Philosophy and the History of Philosophy, vol. 1, Washington, D.C., The Catholic University of America Press, 1961, p. 139-159.

Rodolfi, A., Il concetto di materia nell'opera di Alberto Magno, Firenze, Galluzo, 2004.

Russi, C., "Causality and Sensible Objects: A Comparison between Plotinus and Proclus", in R. Chiaradonna, F. Trabattoni (eds), Physics and Philosophy of Nature in Greek Neoplatonism. Proceedings of the European Science Foundation Exploratory Workshop (Il Ciocco, Castelvecchio Pascoli, June 22-24, 2006), Leiden / Boston, Brill, 2009, p. 145-171.

Schlanger, J., La philosophie de Salomon Ibn Gabirol, Leiden, Brill, 1968.

Siorvanes, L., Proclus. Neo-Platonic Philosophy and Science, Edinburgh, Edinburgh University Press, 1996.

Thijssen, J.M.M.H., "The Debate over the Nature of Motion: John Buridan, Nicole Oresme and Albert of Saxony. With an Edition of John Buridan's Quaestiones super libros Physicorum, secundum ultimam lecturam, Book III, Q. 7", in Early Science and Medicine 14/1(2009), p. 186-210.

Van Riel, G., "Proclus on Matter and Physical Necessity", in R. Chiaradonna, F. Trabattoni (eds), Physics and Philosophy of Nature in Greek Neoplatonism. Proceedings of the European Science Foundation Exploratory Workshop (Il Ciocco, Castelvecchio Pascoli, June 22-24, 2006), Leiden / Boston, Brill, 2009, p. 231-255.

Wengel, P.M., Die Lehre von den rationes seminales bei Albert dem Grossen: Eine terminologische und problemgeschichtliche Untersuchung, Würzburg, Richard Mayr, 1937.

Wieland, G., Untersuchungen zum Seinsbegriff im Metaphysikkommentar Alberts des Grossen, Münster i.W., Aschendorff, 1972. 